\title{
Geogebra Destekli Öğretimin İlköğretim Matematik Öğretmeni Adaylarının Akademik Performanslarına ve Motivasyonlarına Etkisi: Diziler Örneği
}

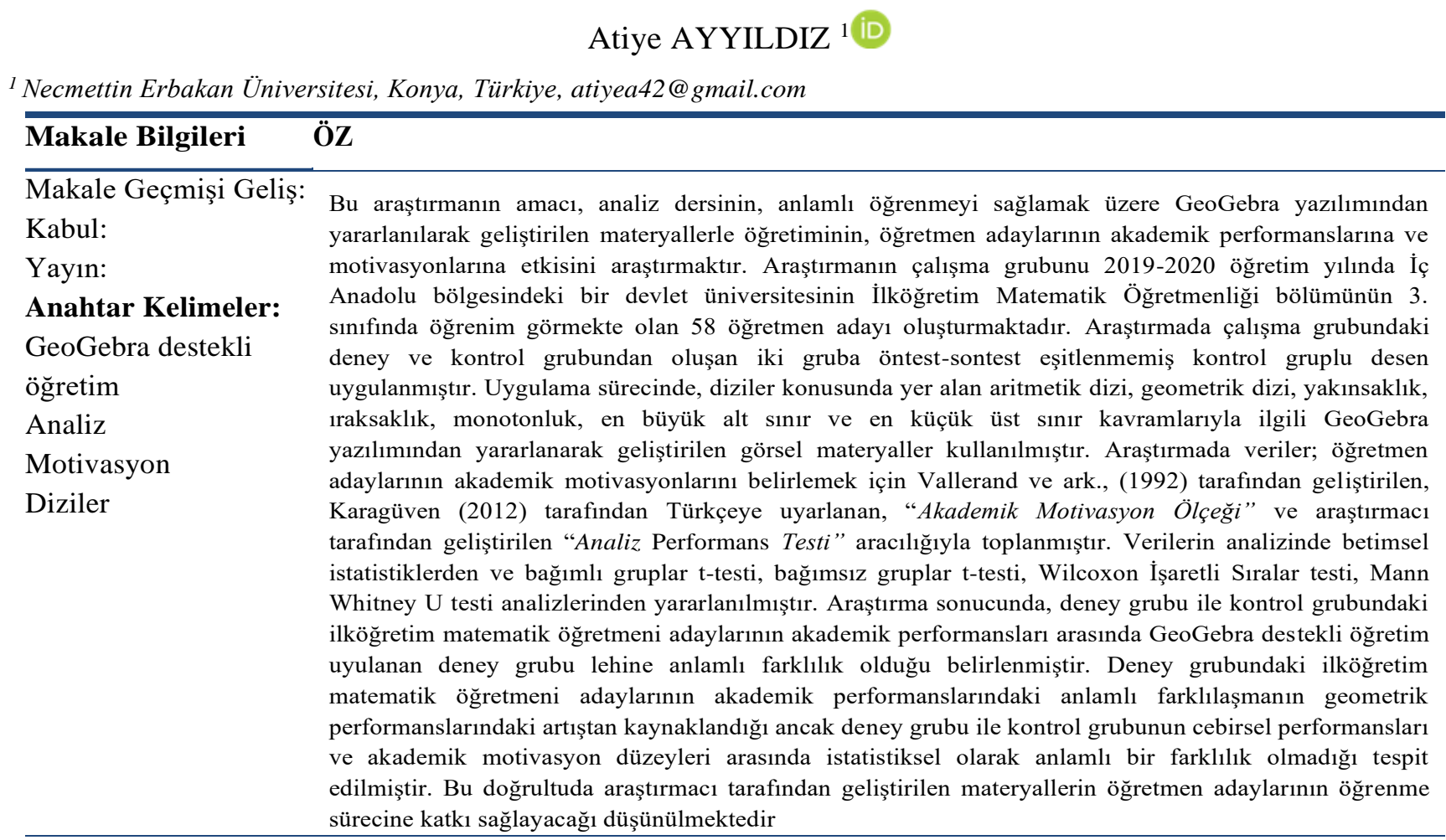

\section{The Effect Of Geogebra Assisted Instruction On Preservice Elementary Mathematics Teachers' Academic Performance And Motivation: A Sample Of Sequences}

\begin{tabular}{|c|c|}
\hline Article Info & ABSTRACT \\
\hline $\begin{array}{l}\text { Article History } \\
\text { Received: } \\
\text { Accepted: } \\
\text { Published: } \\
\text { Keywords: } \\
\text { Geogebra assisted } \\
\text { instruction } \\
\text { Analysis } \\
\text { Motivation } \\
\text { Sequences }\end{array}$ & $\begin{array}{l}\text { This study was conducted to investigate the effect of GeoGebra assisted in order to improve materials for } \\
\text { meaningful learning that used analysis instruction, on pre-service elementary mathematics teachers' } \\
\text { academic performance and motivation. The sample consists of } 58 \text { third grade preservice elementary } \\
\text { mathematics teachers who were registered to an Educational Faculty of Central Anatolia Region in 2019- } \\
2020 \text { academic year. In research, pretest-posttest control group experimental design was applied. In the } \\
\text { application process, visual materials developed by GeoGebra, connected with concepts of arithmetic } \\
\text { sequence, geometric sequence convergence, divergence, monotone sequence, infimum, supremum. In } \\
\text { research to determine academic performance of pre-service elementary mathematics teachers', } \\
\text { Performance Test of Analysis has been prepared by researcher and to determine academic motivation, } \\
\text { Academic Motivation Scale has been prepared by Vallerand et al. (1992) and has been adapted by } \\
\text { Karagüven (2012). In order to analyze obtained data, descriptive istatistics, dependent samples t-test, } \\
\text { independent Samples t-test, Wilcoxon Signed Rank test, Mann Whitney U test were used. The result of } \\
\text { study, significant differecence were found between groups' academic performances in favor of } \\
\text { experimental group however, there is no significant difference between the experiment and control groups } \\
\text { with respect to algebraic performance and academic motivation. The significant difference on academic } \\
\text { performance of pre-service elementary mathematics teachers in experimental group stemmed from } \\
\text { increasing their geometric performance. Accordingly, it is thought that materials, developed by researcher } \\
\text { will contribute to the learning process of pre-service teachers. }\end{array}$ \\
\hline
\end{tabular}




\section{GíRiş}

Analiz dersi, disiplin içinde, disiplinler arası alanda ve günlük hayatta geniş uygulama alanına sahip, üniversitelerin matematik, mühendislik, fizik gibi bölümlerinin ilk yıllarında verilen temel disiplinlerden biridir (Girard, 2002; Hughes-Hallet, Gleason ve McCallum, 2008). Bununla birlikte lisans düzeyinde, analiz dersine kayıtlı olan öğrencilerin birçoğu öğrenmede zorluklar yaşamaktadır (Hughes-Hallet, 1991). Analiz dersini alan öğrencilerin işlemsel algoritmaları rahatlıkla yapabildikleri ancak temel tanım ve yorum bilgilerinde eksikleri olduğu, kavramsal anlama ve kavramlar arası ilişkilendirmede zorluklar yaşadığ ortaya konmaktadır (Chappell ve Kilpatrick, 2003). Öğrencilerin zorlandığı ve çeşitli yanılgılara sahip olduğu (Özmantar ve Yeşildere, 2008), ileri düzey matematiksel düşünme gerektiren (Cornu, 1991) süreklilik, türev, integral, seri kavramlarıyla ilişkili ve matematiksel düşünmeyi geliştirmede etkili olan (Tall, 1992) en temel kavramlardan biri limit kavramıdır. Dolayısıyla matematik eğitiminde önemli bir yeri olan limit kavramıyla ilgili yapılan çalışmalar eski yıllara dayanmakla birlikte (Tall ve Schwarzenberger, 1978; Tall ve Vinner, 1981; Davis ve Vinner, 1986; Williams, 1991; Monaghan, 1991; Bezuidenhout, 2001; Przenioslo, 2004; Roh, 2005; Özmantar ve Yeşildere, 2008; Moru, 2009) fonksiyon özel bir hali olan dizilerin limitini konu alan çalışmaların ise daha çok son yıllarda sayısında bir artış olduğu gözlenmektedir (Mamona-Downs, 2001; Burn, 2005; Roh, 2008; Roh, 2010). Limit kavramına ilişkin yapılan bu çalışmalarda; kavram imajının belirlenmesi, kavramın öğretimi, kavram yanılgılarının ve yaşanılan zorlukların belirlenmesi ve giderilmesi üzerine yoğunlaşıldığını göstermektedir. Gerek genel anlamda fonksiyonlarda limiti gerekse dizilerde limiti konu alan çalışmalar öğrencilerin limit kavramının formal tanımını anlamakta zorlandığını (Bezuidenhout, 2001; Mamona-Downs, 2001; Roh, 2008) ve limitin formal tanımının anlaşılması için ileri düzey matematik bilgisi gerektiğini (Kepçeoğlu, 2010) göstermektedir. Ayrıca limit kavramına ilişkin yapılan çalışmalardan elde edilen sonuçlardan biri de bu zorlukları ortadan kaldırmak için formal tanımla birlikte kavram imajının geliştirilmesi gerektiğidir (Cottrill ve ark., 1996). Öğretim sürecinin zenginleştirilmesi kavram imajlarını geliştirebilmektedir. Nitekim öğretim sürecinde geleneksel öğretim dışında tercih edilen bir tekniğin kavram imajını zenginleştirdiğini ve tanımla uyuşan kavram imajına sahip öğrencilerin daha başarılı olduklarını gösteren çalışma bulunmaktadır (Öner, 2013).

Diğer taraftan, geleneksel öğretim sürecinde, kavramlar arası ilişkilendirme, soyutlama ve genelleme gibi becerilerden daha çok işlemsel becerilerin gelişmesinden (Hughes-Hallet, 1991) ve bu becerilerin limitin formal tanımını anlamak için yetersiz olmasından dolayı geleneksel öğretimden farklı öğretim yöntemlerinden yararlanılan çalışmalar bulunmaktadır (Cottrill ve ark., 1996; Mamona-Downs, 2001). Ancak yapılan bu çalışmalarda duyuşsal becerilerden çok bilişsel beceriler üzerine yoğunlaşılmıştır. Yapılandırmacı öğrenme yaklaşımına dayalı gerçekleştirilen (İnan, 2017); probleme dayalı öğrenme (Ersoy, 2012), proje tabanlı öğrenme (Yıldız, 2008), 5E modeli (Hiçcan, B. 2008; Hülya, 2019) gibi yöntem, teknik ve modeller bilişsel becerilerin yanı sıra ilgi, tutum, öz güven öz yeterlilik, motivasyon gibi duyuşsal becerilerin de gelişimini sağlamaktadır. Duyuşsal becerilerden derse karşı ilgiyi (Tatar, Kağızmanlı ve Akkaya, 2014), öz güveni (Zengin, 2017), tutumu (Doğan, 2010) olumlu yönde etkileyen, kaygıyı azaltan (Barçın, 2019) ve bununla birlikte kavramsal anlama düzeyini geliştiren (kabaca, 2006; Ocal, 2017), matematiksel kavramların farklı temsillerini ilişkilendirmeyi (Kan, 2014) ve anlamlı öğrenmeyi (Ocal, 2017) sağlayan, kavramlara ilişkin bakış açısını olumlu yönde etkileyen (Kepçeoğlu, 2010), kavram imajını zenginleştiren (Öner, 2013) öğrencinin sürece aktif katıldığı (Kepçeoğlu, 2010) tekniklerden biri de teknoloji destekli öğretimdir.

Teknolojinin hızla gelişmesi sonucunda teknolojinin sağladığı imkânlarla birçok yazılım matematik öğretiminde kullanılmaktadır. Bu yazılımlardan Derive, Mathematica, Maple, Matlab veya Mupad vb. gibi bilgisayar cebiri sistemleri; sayısal, cebirsel, grafiksel ve istatistiksel gösterimleri sunan matematik öğreniminde kullanılabilecek etkili bir yazılım (Pierce ve Stacey, 2002) iken Cabri Geometry, Geometer's Sketchpad vb. gibi dinamik geometri yazılımları; yapı içerisindeki sabit ilişkileri görme, değişken değiştirerek yeni durumlar elde etme, bunları analiz etme ve böylece deneyimlerden yararlanarak çıkarımda 
bulunabilme gibi imkânlar sağlamaktadır (Kağızmanlı ve Tatar, 2012; Güven ve Karataş, 2003). GeoGebra ise bilgisayar cebiri sistemlerinin ve dinamik geometri yazılımlarının özelliklerini bir arada bulunduran geometriyi ve cebiri bir arada görme imkânı sağlayan (Edwards ve Jones, 2006; Hohenwarter ve Jones, 2007), keşfetme, genelleme, akıl yürütme gibi matematiksel becerileri destekleyen (Ceylan, 2012) etkileşimli, dinamik bir matematik yazılımıdır (Preiner, 2008; Dikovic, 2009). İlköğretimden itibaren öğrenim-öğretim sürecinin her kademesinde (Hohenwarter ve Jones, 2007) kullanılan, öğrenmeyi kolaylaştıran (Taş, 2010) bu yazılım öğrenim-öğretim sürecinde öğrenciye kavramları somutlaştırma, çıkarımda bulunma (Kağızmanlı ve Tatar, 2012), görselleştirme (Lu, 2008; Dikovic, 2009; Kağızmanlı ve Tatar, 2012), kavramsal öğrenme, kavramları ilişkilendirme, kalıcı öğrenme imkânı sunmasının yanı sıra öz güveni geliştirmekte ve öğrenme ortamını ilgi çekici ve eğlenceli hale getirmektedir (Zengin, 2017). Öğretim sürecinin verimli olması için öğrencinin derse ilgi duymasıyla birlikte sürece aktif katılımı beklenmektedir. Aktif katılım ve dolayısıyla anlamlı öğrenme imkânı elde etmek için öğrencinin istekli olması (Bacanlı ve Şahinkaya, 2011) ve isteklilik halini sürdürmesi gerekmektedir. Bireyi harekete geçirecek nedenlerin olması ve isteklilik halini sürdürebilmesi motivasyonu ile ilgilidir.

Davranış; bireyin biyolojik, psikolojik gelişimi ve sosyal çevresiyle etkileşimi gibi birtakım etkenlere bağlı olarak oluşmaktadır (Danış, 2006). Bireylerin motivasyonunda ve dolayısıyla davranış oluşumunda etkili olan değişkenler bireyden bireye değişmekle birlikte bireysel farklılıklara sahip bireyleri başarılı olmaları yönünde motive edecek etkili unsurların bilinmesi gerekmektedir. Bireylerin bazıları istekleri doğrultusunda motive olurken bazıları ise dışsal kaynaklardan etkilendiği için motive olmaktadır (Ryan ve Deci, 2000). Bireyi öğrenmeye teşvik eden sebeplerin kaynağına göre motivasyon; iç motivasyon, dış motivasyon olmak üzere ikiye ayrılmaktadır. İç motivasyon, bir hareketi amaç olarak görerek zevk almak için sürdürme dürtüsü, diş motivasyon ise bir hareketi amaca ulaşmada araç olarak sürdürme dürtüsüdür (Karagüven, 2012). Merak, kendini geliştirme isteği, bilme ihtiyacı içsel motivasyon; not, ödül veya övgü alma, cezadan kurtulma, rekabet etme gibi olumlu ya da olumsuz pekiştireçler dışsal motivasyon kaynaklarındandır (Akbaba, 2006). Bir aktiviteyi gerçekleştirmek için herhangi bir isteğin, nedenin veya gücün olmaması ise motivasyonsuzluk (Ryan ve Deci, 2000) olarak değerlendirilmektedir. İçsel motivasyonda isteklilik; kişinin ilgisini çekmesi, merak uyandırması gibi iç etkenlere bağlıyken, dışsal motivasyonda isteklilik; başkasının övgüsünü veya ödülünü almak gibi dış etkenlere bağlıdır (Ryan ve Deci, 2000). Psikoloji ve eğitimde motivasyonla ilgili teorilerde, başarı ile arasında pozitif bir ilişki olan içsel motivasyon (Lepper, Corpus ve lyengar, 2005) ve içsel motivasyon ile arasında negatif bir ilişki olan dışsal motivasyona (Lepper, Corpus ve lyengar, 2005) ilişkin çalışmalar bulunmaktadır. Bu çalışmada akademik motivasyonu ölçmek için kullanılan ölçek ise içsel motivasyon, dışsal motivasyon, motivasyonsuzluk alt boyutlarını içeren kapsamlı bir ölçektir.

Literatür incelendiğinde; dizileri (Burn, 2005; Roh, 2008; Roh, 2010; Mamona-Downs, 2001) GeoGebra destekli öğretimi (Kepçeoğlu, 2010; Gómez-Chacón ve Escribano, 2011; Zengin, Furkan ve Kutluca, 2012; Aydos, 2015; Kepçeoğlu ve Yavuz, 2017; Çirişoğlu ve Kaçar, 2019), fonksiyonlarda limitin teknoloji destekli öğretimini (Parks, 1996; Büyükkoroğlu ve ark., 2006; Kabaca, 2006; Çetin, 2009), GeoGebra destekli öğretim ve motivasyonu (Gunčaga, 2011; Wah, 2015) ve ilköğretim düzeyinde GeoGebra destekli öğretimin akademik performansa ve motivasyona etkisini (Wah, 2015, Ünlütürk-Akçakın, 2016) inceleyen birçok çalışma bulunmakla birlikte ulaşılan alan yazında lisans düzeyinde diziler kavramının GeoGebra destekli öğretiminin akademik performansa ve motivasyona etkisini inceleyen bir deneysel çalışmaya rastlanmamıştır. Bununla birlikte, öğretmen adaylarının disiplin içinde temel alanlardan biri olan analiz dersindeki (Girard, 2002; Hughes-Hallet, Gleason ve McCallum, 2008) özellikle limit kavramına ilişkin kavram yanılgılarının, süreklilik (Bezuidenhout, 2001), seri (Sierpinska, 1987) gibi kavramları ögrenmelerini ve lisans öğrenimi boyunca aldıkları diğer derslerde akademik performanslarını olumsuz yönde etkileyebileceği düşünülmektedir. Bununla birlikte, yapılan çalışmalar öğretmen adaylarının büyük çoğunluğunun yakınsaklığın tanımında geçen $\varepsilon-N\left(\varepsilon-n_{\varepsilon}\right)$ değişkenlerini anlamlandırmada zorlandıklarını 
(Roh, 2008) ve öğretim sürecinde yararlanılan görselleştirmelerin bu formal tanımı anlamlandırmada ve kavram imajı geliştirmede (Parks, 1996; Navarro ve Carreras, 2006; Kidron ve Zehavi, 2002; Öner, 2013) etkili olabileceğini göstermektedir. Ayrıca, geleneksel öğretim haricinde uygulanan yöntem ve tekniklerin, duyuşsal özelliklerden, akademik performans üzerinde önemli ölçüde etkili olan akademik motivasyonu (Elliot ve Thrash, 2001; Matuga, 2009) etkileyebileceği hususu akla gelmektedir. Bundan dolayı analiz dersindeki kavramların öğrenimi ve öğretiminde önemli bir rolü olan görselleştirmenin (Pinto ve Tall, 2002) sağlanabileceği tekniklerden biri olan Geogebra destekli öğretimin (Kağızmanlı ve Tatar, 2012) geleneksel öğretime göre daha zengin uygulamalar yapma imkânı sunması açısından, bilişsel ve duyuşsal becerilere etkisinin araştırılması önemlidir. Bu araştırmada, analiz dersinde uygulanan GeoGebra destekli öğretimin öğretmen adaylarının, akademik performanslarına ve motivasyonlarına etkisinin tespitiyle analiz eğitimcilerine yol göstermesi bakımından matematik eğitimine katkı sağlayacağı düşünülmektedir. Bu anlamda "Analiz dersinde GeoGebra destekli öğretimin ilköğretim matematik öğretmeni adaylarının akademik performanslarına ve motivasyonlarına etkisi nedir?” problemi çerçevesinde aşağıdaki sorulara cevap aranmıştır.

\section{Araştırma Soruları}

1. Analiz dersinde GeoGebra destekli öğretimin uygulandığı deney grubundaki ilköğretim matematik öğretmeni adaylarının; Analiz Performans Testinden ve Akademik Motivasyon Ölçeğinden aldıkları ön testson test puanları arasında anlamlı bir farklılık var midır?

2. Analiz dersinde geleneksel öğretim yapılan kontrol grubundaki ilköğretim matematik öğretmeni adaylarının; Analiz Performans Testinden ve Akademik Motivasyon Ölçeğinden aldıkları ön test-son test puanları arasında anlamlı bir farklılık var mıdır?

3. Analiz dersinde, GeoGebra destekli öğretimin uygulandığı deney ve geleneksel öğretim yapılan kontrol grubundaki ilköğretim matematik öğretmeni adaylarının; Analiz Performans Testinden ve Akademik Motivasyon Ölçeğinden aldıkları son test puan ortalamaları arasında anlamlı bir farklılık var mıdır?

\section{YÖNTEM}

Üniversitede sınıflar üniversite yönetimi tarafindan oluşturulduğundan öğretmen adaylarının sınıflarını değiştirme imkânı bulunmamaktadır. Bu nedenle deney ve kontrol gruplarına seçkisiz atama yapılamayacağından, üniversitede gerçekleştirilen eğitim araştırmalarında gerçek deneysel modelin kullanılmasının mümkün olmadığı durumlarda, yönetim tarafindan daha önceden oluşturulmuş gruplardan bir veya birkaçının deney grubu ve kontrol grubu olarak rastgele belirlendiği model yarı deneysel model olarak adlandırılmaktadır (Özmen, 2016). Bu araştırmada; GeoGebra destekli öğretimin, öğretmen adaylarının akademik performanslarına ve motivasyonlarına etkisinin incelenmesinde ön test son test eşitlenmemiş kontrol gruplu deneysel model kullanılmıştır. Araştırma sürecinde deney grubu üzerinde etkisine bakılacak bağımsız değişken, GeoGebra destekli öğretimdir. Bu nedenle deney grubunda GeoGebra destekli öğretim tekniği, kontrol grubunda ise geleneksel öğretim yöntemi kullanılmıştır. Araştırma sürecinde deney ve kontrol grubuna analiz dersinin öğretimi araştırmacı tarafından gerçekleştirilmiştir. 
Tablo 1.

Ön Test-Son Test Eşitlenmemiş Kontrol Gruplu Model

\begin{tabular}{lccc}
\hline $\mathrm{G}_{1}$ & $\mathrm{O}_{1.1}$ & $\mathrm{X}_{1}$ & $\mathrm{O}_{1.2}$ \\
\hline $\mathrm{G}_{2}$ & $\mathrm{O}_{2.1}$ & $\mathrm{X}_{2}$ & $\mathrm{O}_{2.2}$ \\
\hline$G_{1}:$ GeoGebra destekli öğretim uygulanan & & $G_{2}:$ Geleneksel öğretim uygulanan grup. \\
grup & & \\
$O_{1.1}, O_{2.1}:$ Ön Test Puanları & & $O_{1.2}, O_{2.2}:$ Son Test Puanları \\
$X_{1}:$ Deney grubunda & uygulanan GeoGebra & $X_{2}:$ Kontrol grubunda uygulanan geleneksel \\
destekli öğretim & & ögretim.
\end{tabular}

Araştırmada ölçme aracı olarak Analiz Performans Testi ve Akademik Motivasyon Ölçeği ön test ve son test olarak kullanılmıştır. Analiz Performans Testi cebirsel ve geometrik temsil sorularından oluşmaktadır. $\mathrm{Bu}$ çalışmada cebirsel temsilden, cebirsel temsille ifade edilen sorular ve geometrik temsilden, geometrik temsille ifade edilen sorular kastedilmektedir. Çalışmada cebirsel performans deyince cebirsel temsille verilen soruları çözme performansı ve geometrik performans deyince geometrik temsille verilen soruları çözme performansı anlaşılacaktır.

\section{Deneysel Uygulama}

Deney ve kontrol grubuna haftalık 3 ders saati olarak işlenen analiz dersinde dizi, aritmetik dizi, geometrik dizi, en büyük alt sınır, en küçük üst sınır, yakınsaklık, 1raksaklık, monotonluk kavramlarını içeren diziler konusunun öğrenimi ve öğretimi eş zamanlı olarak 15 ders saatinde (5 hafta) gerçekleştirilmiştir. Deney ve kontrol grubundaki öğretmen adaylarına, dizi, dizinin limiti, aritmetik dizi, geometrik dizi, en büyük alt sınır, en küçük üst sınır gibi bazı kavramlar ortaöğretimde öğrendikleri bilgileriyle ilişkilendirilerek yapılandırılmasıyla birlikte, ilk defa gördükleri tanım ve teoremler hazır bir şekilde sunulmuştur. Her iki gruba kavramların öğretiminin ardından soru çözümü yapılmıştır. Geleneksel öğretimim uygulandığı kontrol grubunda dersler doğrudan anlatım, soru cevap teknikleri kullanılarak gerçekleştirilmiştir.

Deney grubunda uygulamaya başlamadan önce GeoGebra yazılımından yararlanarak gerçekleştirilecek olan dersler ile ilgili bilgi verilmiştir. Öğretmen adayları lisans öğrenimlerinde daha önce aldıkları bir derste GeoGebra yazılımının kullanımını öğrendiklerinden bununla ilgili herhangi bir çalışma yapılmamıştır. Ancak uygulamaya başlamadan önce GeoGebra yazılımı ile ilgili örnek uygulamalar gösterilmiştir ve uygulama sürecinde kullanılmayacak bir uygulama, örnek olması açısından öğretmen adaylarına yaptırılmıştır.

\section{Teknoloji destekli öğretimin uygulandı̆̆ı deneysel süreç}

Kavramların farklı temsillerini bir arada sunmanın yanı sıra işlemsel algoritmaların sonucunu hazır bir şekilde elde etme avantajı sağlaması ve bununla birlikte öğrenme sürecinde işlemlerle vakit harcamak yerine, zamanın verimli bir şekilde kullanılması sonucu istenilen amaçlar için uğraşılmasına daha çok imkân tanımasından (Aktümen, Yıldız, Horzum ve Ceylan, 2011) dolayı öğretmen adaylarına kavramların formal yapısı üzerinde düşünmeleri için imkân sunabileceği düşüncesiyle deneysel süreçteki örnekler ve görsellerin tamamı GeoGebra yazılımı kullanılarak oluşturulmuştur. Dizi, aritmetik dizi-geometrik dizi, en büyük alt sınır-en küçük üst sınır, yakınsaklık, 1raksaklık, monotonluk kavramlarını somut ve görsel hale getirmeye yönelik toplam 6 materyal hazırlanmıştır. Araştırmacı tarafından hazırlanan materyaller temelinde deney grubunda öğretim süreci, kontrol grubundan farklı olarak öğretmen adaylarının keşfederek öğrenmesine yönelik gerçekleştirilmiştir. Öğretim sürecinde 
öğretmen adaylarına öncelikle materyaller üzerinde düşünme ve deneyim geçirme imkânı verilmiştir. Daha sonra materyalle ilgili deneyimlerini ve edindikleri bilgileri aktarmaları için öğretmen adaylarından çalışma kağıdındaki sorulara sınıftan bağımsız bir şekilde cevap vermeleri istenmiştir. Çalışma kağıtları toplandıktan sonra öğretmen adaylarına bilgilerini paylaşma ve tartışma imkânı verilmiştir. $\mathrm{Bu}$ sürecin ardından öğretmen adaylarına geri bildirimde bulunulmuştur. Öğretim süreci boyunca araştırmacı, öğretmen adaylarına eksik bilgilerini fark etmeleri ve tamamlamaları için rehberlik etmiştir.

Hazırlanan materyallerden örnekler; Şekil 1, Şekil 2 ve Şekil 3' te verilmektedir. Dizi kavramının tanımı ile ilgili materyal Şekil 1' de verilmektedir.

\section{Şekil 1.}

Dizi kavramının tanımına ilişkin materyal

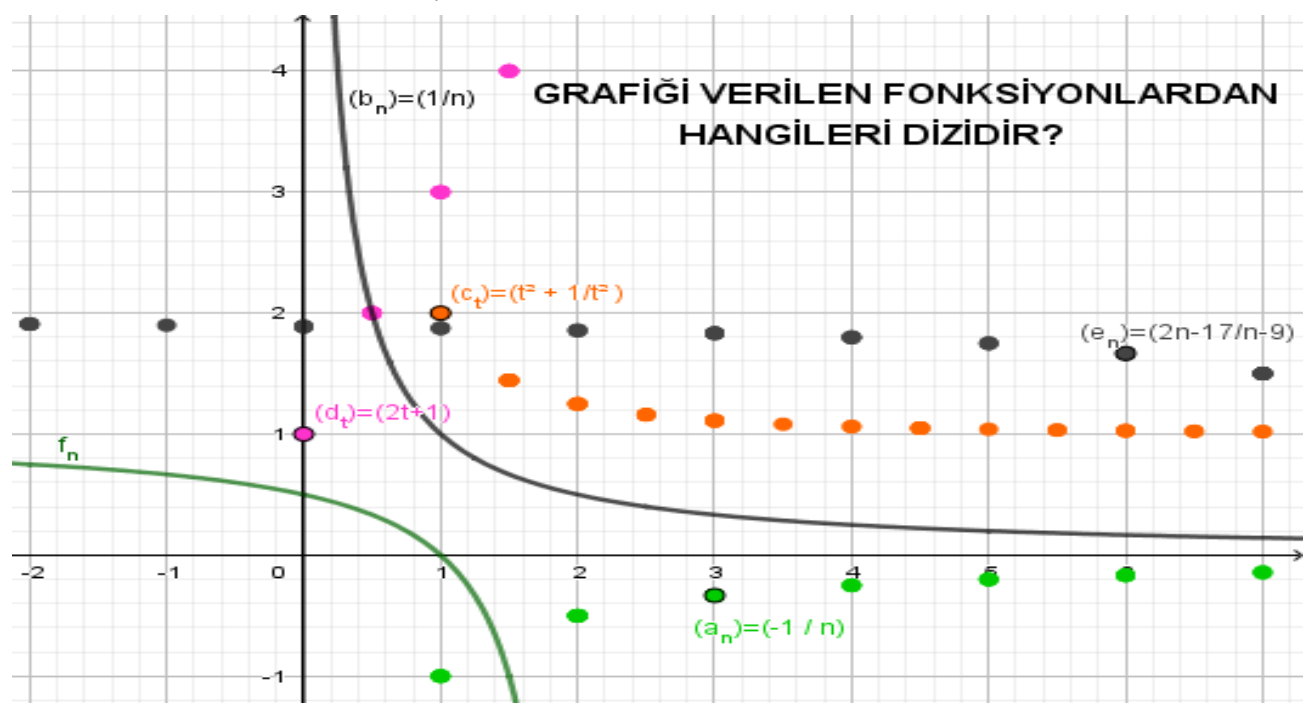

$\mathrm{Bu}$ materyal; fonksiyonların cebirsel ifadesini, tanımlı olduğu kümeyi ve grafiğini; cebir ve grafik penceresinde aynı ara yüzde görebilme ve dizilerin tamamının fonksiyon olmasına rağmen, her fonksiyonun bir dizi belirtmeyeceği çıkarımında bulunabilme imkânı sunmaktadır. Ayrıca, materyal dizilerin tanım kümesi doğal sayılardan oluşan bir fonksiyon olmasından dolayı sürekli olmadığını ve bu durumun dizinin grafiğine yansımasını değerlendirme ve ilişkilendirme olanağı sağlamaktadır. Nitekim literatürde; fonksiyonun tanım kümesine (Özmantar ve Yeşildere, 2008), fonksiyonların yalnızca sürekli eğrilerden oluştuğuna (Bayazit ve Aksoy, 2013) ve ayrık noktalardan oluşan grafiklerin fonksiyon belirtmediğine (Dubinsky ve Harel, 1992) ilişkin yanılgılara rastlanmaktadır. Bu materyalin, öğretmen adaylarının yanılgılarını ortadan kaldırabileceği ve bu açıdan öğrenme sürecine katkı sağlayabileceği düşünülmektedir. Dizilerde yakınsaklık kavramı ile ilgili materyal, Şekil 2' de gösterilmektedir. 


\section{Şekil 2.}

Dizilerde yakınsaklık kavramına ilişkin materyal

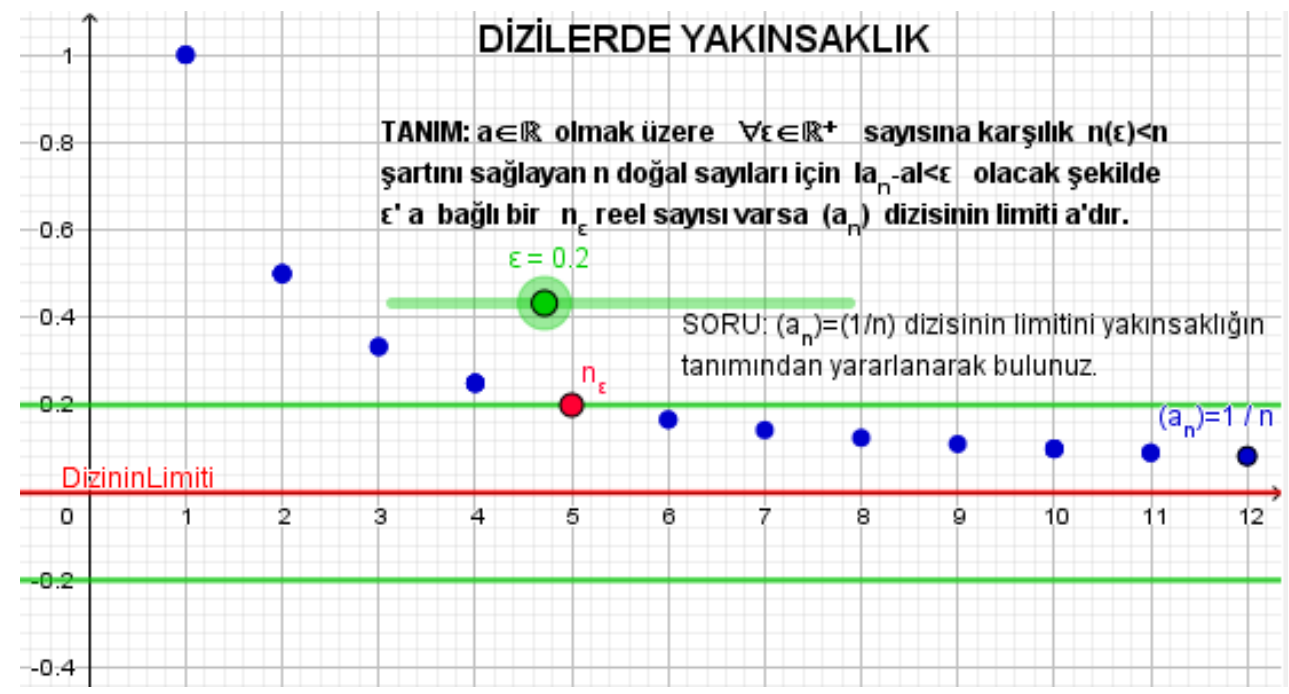

$\mathrm{Bu}$ materyal; GeoGebra yazılımının sürgü özelliğinden yararlanarak değiştirlebilen $\varepsilon$ değerlerine karşı1ık $n_{\varepsilon}$ değerinin değişimini izi aç özelliğini kullanarak grafik üzerinde anında görme, bu iki değişken arasındaki ilişkiyi keşfetme ve dolayısıyla yakınsaklığın tanımını içselleştirme olanağı sağlamaktadır. Ayrıca materyal, yazılımın izi açma özelliğinden dolayı yakınsak bir dizinin sonlu sayıda elemanının, limit değerinin komşuluğu dışında, ıraksak dizilerin ise sonlu sayıda elemanının, limit değerinin komşuluğu içinde yer aldığını somut bir şekilde sunmaktadır.

Dizilerin limiti kavramının öğretimi sürecinde öncelikle öğretmen adayından önceki bilgilerini kullanarak fonksiyonun limitinin özel bir hali olan (tanım kümesi doğal sayılardan oluşan) dizilerin limitini, limit alınan noktanın sonsuza gitmesi durumunu dikkate alarak belirlemeleri beklenmiştir. Öğretmen adaylarından daha çok işlemsel süreçler uygulayarak belirledikleri limit değerini bu materyali kullanarak ve çalışma kağıdındaki sorularla; limitin formal tanımıyla ilişkilendirmeleri, formal tanımda geçen $\varepsilon,{ }^{n}$ değişkenlerinin ve $\left|a_{n}-a\right|<\varepsilon$ eşitsizliğinin taşıdığı anlamı sorgulamaları istenmiştir. Dizilerde limitin tanımında geçen $\varepsilon$ değerlerine karşılık $n_{\varepsilon}$ değerinin ters orantılı olarak değiştiğini ancak yakınsak bir dizinin tek bir limitinin olduğunu (materyaldeki kırmızı çizgi) ve $\left|a_{n}-a\right|<\varepsilon$ eşitsizliğinin $\left(a_{n}\right)$ dizisinin limiti olan $a$ değerinin $\varepsilon$ komşuluğu (materyaldeki yeşil çizgilerle gösterilen aralık) içinde kalan elemanlarını $\left(a_{n} \in(a-\varepsilon, a+\varepsilon)\right.$ ) ifade ettiğini keşfetmeleri beklenmiştir. Bununla birlikte yakınsak bir dizide sonlu sayıda elemanın (dizinin $n<n_{\varepsilon}$ şartını sağlayan $a_{n}$ elemanlarının) $a^{\prime}$ nın $\quad \varepsilon$ komşuluğu dışında ve sonsuz sayıda elemanın $a^{\prime}$ nın $\varepsilon$ komşuluğu içinde kaldığını belirtmek için tanımda $\varepsilon$ ve $n_{\varepsilon}$ değişkenlerinden yararlanıldığı vurgulanmıştır. Dizilerde en küçük üst sınırı ve en büyük alt sınırı bulmaya ilişkin bir materyal örnek olarak Şekil 3' te gösterilmektedir. 
Şekil 3.

Dizilerde en küçük üst sınır ve en büyük alt sınıra ilişkin bir materyal

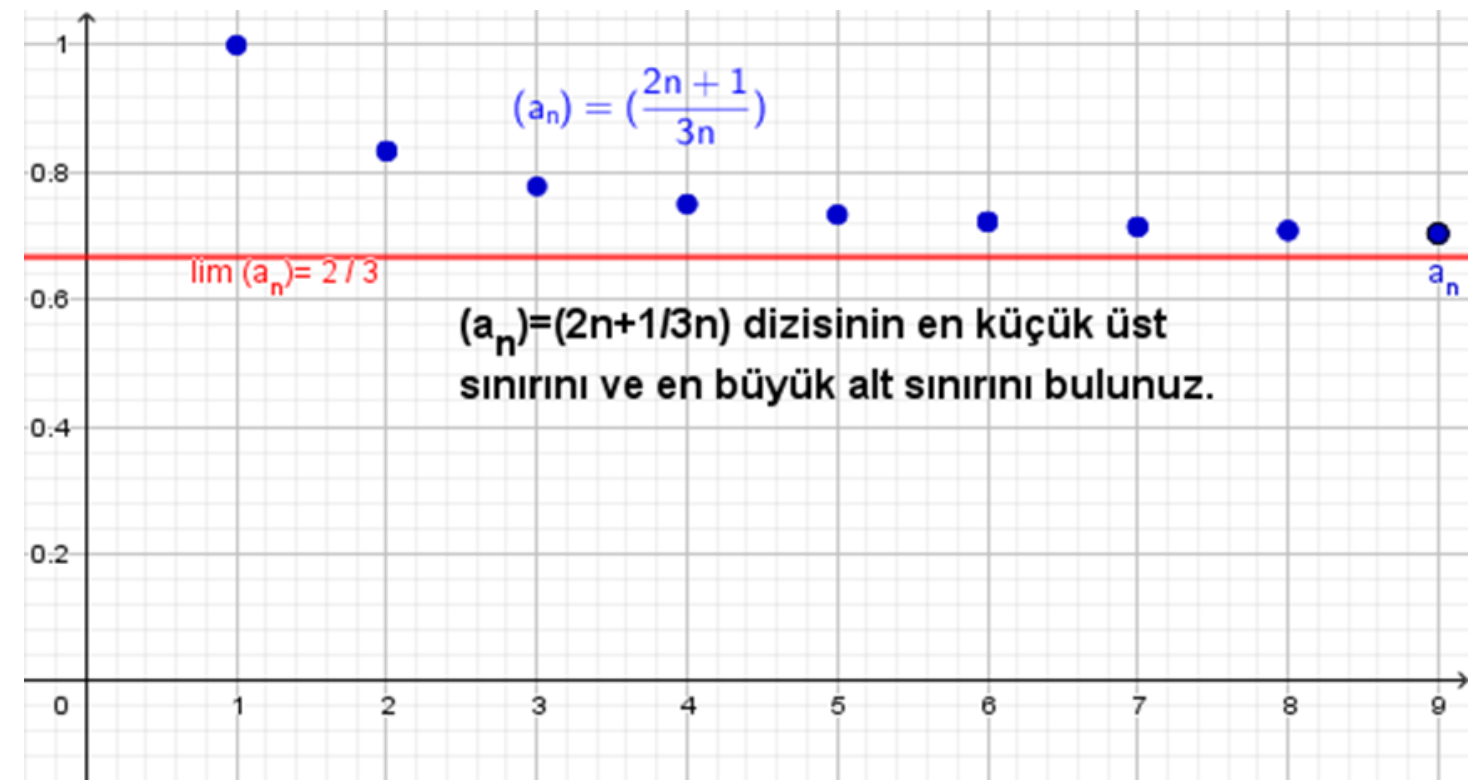

Bu materyal; yazılımın işlemsel algoritmaları hesaplama özelliğinden yararlanarak dizilerin limitini hazır bir şekilde elde etme, grafik penceresinde yakınsak dizilerin en küçük üst ve en büyük alt sınırını belirleme ve bu kavramlar arasındaki ilişkiyi görme olanağı sağlamaktadır. Ayrıca materyal; öğretmen adaylarının sınırlı dizilerin her birinin yakınsak olmadığı yani ıraksak dizilerin de sınırlı olabileceği çıkarımında bulunmalarına imkân tanımaktadır. Öğretmen adayları, ortaöğretimde ve lisansta önceki yıllarda limit, en küçük üst sınır, en büyük alt sınır ve monotonluk kavramlarını görmüş olsa da bu kavramlarla ilgili anlamlı öğrenmenin gerçekleşmediği uygulamaya başlamadan önce ön testlerin değerlendirme sürecinde tespit edilmiştir. Öğretmen adaylarının çoğunun en küçük üst ve en büyük alt sınırın dizinin elemanı olması gerektiği yanılgısına sahip olduğu görülmüştür. Bu materyalin bu yanılgıları ortadan kaldırabileceği ve anlamlı öğrenmeyi sağlayabileceği düşünülmektedir. Öğretmen adaylarının birçok örnek üzerinden değerlendirme yapabilmeleri ve çıkarımda bulunabilmeleri için GeoGebra yazılımı ile benzer uygulamalar hazırlanmıştır.

\section{Çalışma Grubu}

Çalışma grubunu 2019-2020 öğretim y1lında İç Anadolu bölgesinde bir devlet üniversitesindeki İlköğretim Matematik Öğretmenliği bölümünde öğrenim görmekte olan iki şubeden oluşan 3. sınıf öğrencileri oluşturmaktadır.

Tablo 4'e göre ölçümlerin normallik analizi sonucunda, grupların bazılarının Analiz Performans Testinden aldıkları cebirsel, geometrik ve genel performans puanlarının parametrik testleri uygulamak için ön koşullardan biri olan normal dağılım göstermediği görülmektedir. Bu durumda iki grubun; cebirsel, geometrik ve genel performans ön test puanlarının, parametrik olmayan testlerden Mann Whitney U testi ile karşılaştırılmasına karar verilmiştir. 
Tablo 2.

Deney ve Kontrol Gruplarındaki Öğretmen Adaylarının Analiz Performans Testi Cebirsel, Geometrik ve Genel Performans Ön Test Puanlarına İlişkin Mann Whitney U Testi Sonuçları

\begin{tabular}{lllllll}
\hline \multirow{2}{*}{ Performans Türü } & Grup & $\mathrm{n}$ & Sira & Sira & & $\mathrm{p}$ \\
\hline Cebirsel performans & Deney & 30 & 984 & Ortalamas1 & $\mathrm{U}$ & 32.80 \\
& Kontrol & 28 & 727 & 25.96 & 321 & .12 \\
\hline Geometrik performans & Deney & 30 & 936 & 31.20 & 369 & .42 \\
& Kontrol & 28 & 775 & 27.68 & & \\
\hline Genel performans & Deney & 30 & 965 & 32.17 & 340 & .21 \\
& Kontrol & 28 & 746 & 26.64 & & \\
\hline
\end{tabular}

Tablo 2' e göre deney ve kontrol gruplarının Analiz Performans testinden aldıkları cebirsel, geometrik ve genel performans ön test puan ortalamaları arasında istatistiksel olarak anlamlı bir fark olmadığ görülmektedir ( $p>.05)$.

Tablo 4'de görüldüğü gibi ölçümlerin normallik analizi sonucunda, grupların Akademik Motivasyon Ölçeğinden aldıkları puanlar normal dağılım göstermektedir. Bu durumda iki grubun Akademik Motivasyon Ölçeği ön test puanlarını karşılaştırmak için bağımsız gruplar t testinden yararlanılmış ve ilgili istatistikler tablo 3' te sunulmuştur.

Tablo 3.

Deney ve Kontrol Gruplarındaki Öğretmen Adaylarının Akademik Motivasyon Ölçeği Ön Test Puanlarına Illişkin Bă̆ımsız Gruplar t testi Sonuçları

\begin{tabular}{lllllll}
\hline Grup & $\mathrm{n}$ & $\bar{x}$ & $S_{x}$ & $\mathrm{Sd}$ & $\mathrm{t}$ & $\mathrm{p}$ \\
\hline Deney & 30 & 115.9 & 24.24 & 56 & 1.03 & .30 \\
Kontrol & 28 & 118.7 & 18.74 & & & \\
\hline
\end{tabular}

Tablo 3'e göre deney gruplarının ve kontrol grubunun Akademik Motivasyon Ölçeği ön test puan ortalamaları arasında anlamlı bir fark olmadığı görülmektedir $(p>.05)$.

$\mathrm{Bu}$ bulgulardan elde edilen sonuçlara göre, akademik performans ve motivasyon bağlamında gruplar homojen olduğundan araştırmanın GeoGebra destekli öğretim yapılacak deney grubunu, ilköğretim matematik öğretmenliği 3. sınıflardan A şubesinde öğrenim gören 30, geleneksel öğretim yapılacak kontrol grubunu ise $\mathrm{B}$ şubesinde öğrenim gören 28 ilköğretim matematik öğretmen adayı oluşturmaktadır. Bu çalışma için deneysel çalışmalarda grupların her birinde en az 15 kişi bulunması şartı sağlanmaktadır (Akarsu, 2016).

\section{Veri Toplama Araçları}

Alanında uzman öğretim üyelerinden alınan görüş doğrultusunda, Yükseköğretim Kurulu tarafından hazırlanan 2019-2020 eğitim-öğretim yılı lisans programında belirtilen analiz dersine ilişkin içerik ve Ortaöğretim Matematik (12.sınıflar) Dersi Öğretim Programındaki kazanımlar (Milli Eğitim Bakanlığ1 [MEB, 2018]) dikkate alınarak Analiz Performans Testinin kavram bazında soru dağılımı belirlenmiştir. Analiz Performans Testi, diziler ve limit kavramına ilişkin daha önceki yıllarda ilköğretim matematik öğretmenliği alan bilgisi ve üniversiteye giriş sınavlarında sorulmuş sorulara paralel olarak hazırlanmıştır. Analiz Performans Testi; dizinin tanımı, aritmetik dizi, geometrik dizi, en küçük üst sınır (sup), en büyük alt sınır (inf), yakınsaklık, rraksaklık ve monotonluk kavramlarına ilişkin 14 olmak üzere testin alt boyutlarıyla birlikte toplam 23 açık uçlu sorudan oluşmaktadır. Bu sorulardan 11'i cebirsel temsil performansını, 12' si geometrik temsil performansını ölçmek için hazırlanmıştır. Analiz Performans Testinde, farklı yöntem ve tekniklerle öğrenim görecek olan gruplardaki öğretmen adaylarının özellikle geometrik ve cebirsel 
performanslarını karşılaştırmak için kavramların her biriyle ilgili cebirsel temsil performansını ölçen soru ile birlikte geometrik temsil performansını ölçen soru bulunmaktadır. Analiz Performans Testinde yer alan monotonluk kavramına ilişkin cebirsel temsil ve geometrik temsil performansını ölçmek için hazırlanan sorulardan örnekler Şekil 4’te gösterilmektedir.

\section{Şekil 4.}

Analiz Performans Testindeki monotonluk kavramına ilişkin örnek sorular

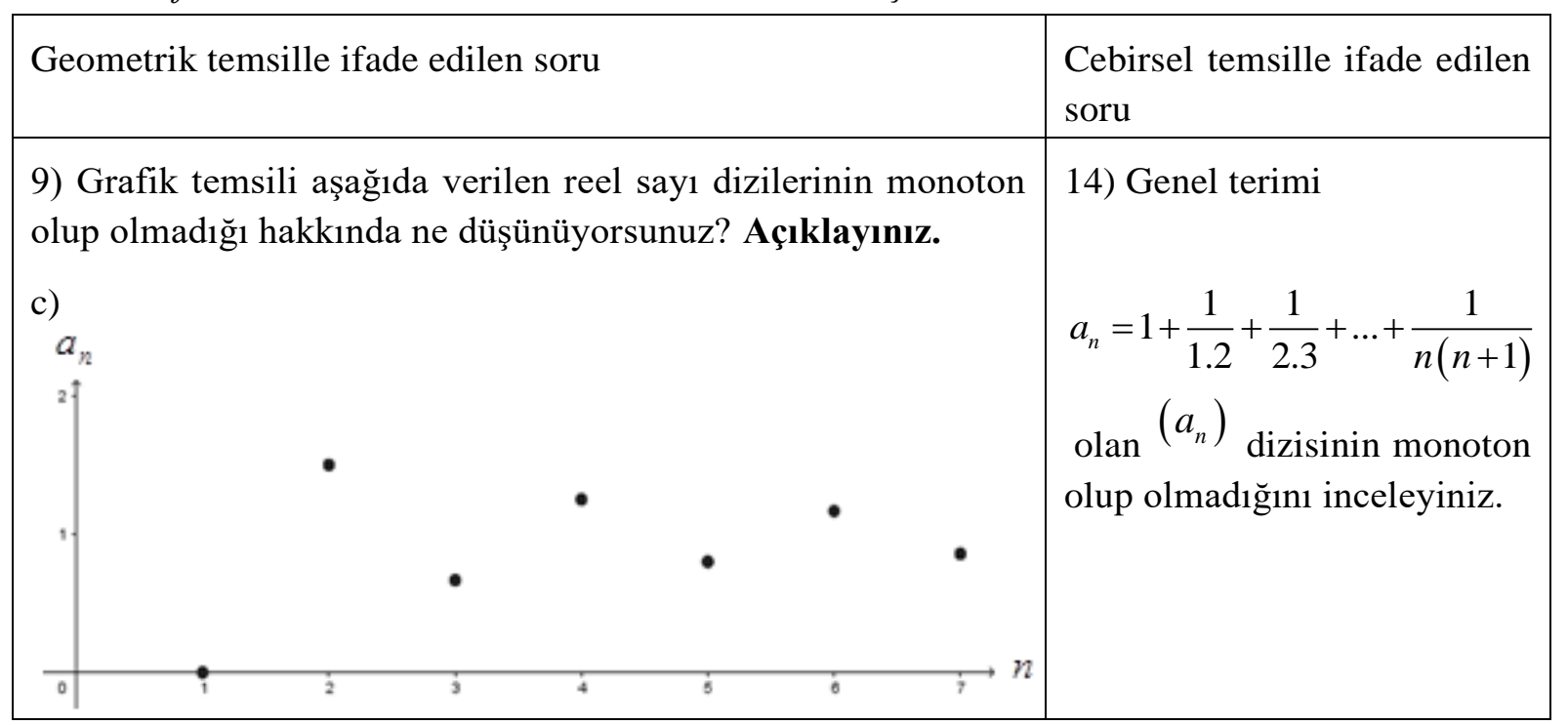

Analiz alanında uzman 1, matematik eğitimi alanında uzman 1 öğretim üyesinden görüş alınarak 2 sorunun ifadesinde ve 1 sorunun grafiğinde değişiklikler yapılmıştır. Alınan görüşler doğrultusunda Analiz Performans Testinin kapsam geçerliliğine sahip olduğu kararlaştırılmıştır. Yapılan düzeltmelerin ardından son halini alan Analiz Performans Testi'nin Cronbach-alfa güvenirlik katsayısı 0,849 olarak hesaplanmıştır. $\mathrm{Bu}$ araştırmada, Analiz Performans Testinin güvenirlik analizinde gözlemciler arası uyumda dikkate alınmıştır. Bunun için öğretmen adaylarının cevap kağıtlarından 10 tanesi seçilmiş ve bu cevap kağıtlarını daha önce analiz dersine girmiş 1 öğretim üyesinin, araştırmacı tarafından hazırlanan rubriği dikkate alarak değerlendirmesi sağlanmıştır. Öğretim üyesinin ve araştırmacının verdiği puanlara ilişkin korelasyon katsayısı 0,743 olarak hesaplanmış ve Analiz Performans Testi'nin güvenilir olduğuna karar verilmiştir.

Akademik motivasyon; öğrenimi ve öğretimi büyük ölçüde etkileyen bir kavram olduğundan diğer duyuşsal özellikler gibi ölçülmek istenen ve bunun için farklı boyutlar dikkate alınarak ölçeklerin hazırlandığı önemli bir kavramdır. Araştırmada öğretmen adaylarının akademik motivasyonu, Vallerand ve ark. (1992), tarafından geliştirilen, Karagüven (2012) tarafından Türkçeye uyarlanan "Akademik Motivasyon Ölçeği” aracılığıyla ölçülmüştür. Ölçme aracındaki maddelerin değerlendirilmesi "Hiç uyuşmuyor=1" ile "tam olarak uyuşuyor=7" arasında değişen 7 dereceye göre gerçekleştirilmiştir. Duyuşsal boyuttaki özellikleri ölçen ölçek, içsel motivasyon bilme, içsel motivasyon başarma, içsel motivasyon hareket, dışsal motivasyon düzenleme, dışsal motivasyon kendini ispat, dışsal motivasyon tanınma, motivasyonsuzluk alt boyutlarının her biri ile ilgili likert tipi 4 madde olmak üzere toplam 28 maddeden oluşmaktadır. Akademik Motivasyon Ölçeği' nin geliştirilmesi (Vallerand ve ark.,1992) ve Türkçeye uyarlanması (Karagüven, 2011) aşamalarında yapılan çalışmalarda ölçeğin güvenilir ve geçerli bir ölçek olduğu belirlendiğinden ve Türkçeye uyarlama çalışmalarında tercih edilen çalışma grubu, bu çalışmadaki ile aynı kademede öğrenim gören öğretmen adaylarından oluştuğundan güvenirlik ve geçerlik çalışmasının tekrarlanmasına gerek görülmemiştir.

Deney ve kontrol gruplarına, Analiz Performans Testi ve Akademik Motivasyon Ölçeği deneysel uygulamaya başlamadan ve uygulamanın tamamlanmasının ardından, ön test ve son test olarak uygulanmıştır. 


\section{Verilerin Analizi}

Kullanılacak olan istatistiksel analizleri belirlemek için, öncelikle yapılan ölçümlerde grupların normal dağılım gösterip göstermedikleri incelenmiştir. Gruptaki gözlem sayıs1 30 ve üzerinde olduğu durumda Kolmogorov-Simirnov; gruptaki gözlem sayıs1 30'un altında olduğu durumda Shapiro-Wilk testlerinin kullanılması uygundur (Can, 2016; s.89). Uygun olan istatistiksel analizin tercih edilmesi için deney grubundaki kişi sayısı 30 olduğundan Kolmogrov Smirnov ve kontrol grubundaki kişi sayısı 28 olduğundan Shapiro Wilks testleri ile incelenen normallik analizleri aşağıdaki tabloda sunulmuştur.

\section{Tablo 4.}

Ön Test-Son Test Ölçümlerinin Normallik Analizleri

\begin{tabular}{|c|c|c|c|c|c|c|}
\hline Ölçüm & Grup & $\mathrm{n}$ & $\bar{x}$ & $S_{x}$ & İstatistik & $\mathrm{p}$ \\
\hline \multirow[t]{2}{*}{ Cebirsel performans-ön test } & Deney Grubu & 30 & 20.77 & 5.79 & .12 & .20 \\
\hline & Kontrol grubu & 28 & 18.75 & 4.54 & .89 & .00 \\
\hline \multirow[t]{2}{*}{ Cebirsel performans-son test } & Deney Grubu & 30 & 24.96 & 4.80 & .14 & .02 \\
\hline & Kontrol grubu & 28 & 24.18 & 4.38 & .94 & .11 \\
\hline \multirow{2}{*}{ Geometrik performans -ön test } & Deney Grubu & 30 & 22.83 & 10.22 & .16 & .04 \\
\hline & Kontrol grubu & 28 & 19.18 & 13.12 & .88 & .00 \\
\hline \multirow[t]{2}{*}{ Geometrik performans-son test } & Deney Grubu & 30 & 28.39 & 7.89 & .29 & .00 \\
\hline & Kontrol grubu & 28 & 22.21 & 10.34 & .84 & .00 \\
\hline \multirow[t]{2}{*}{ Genel performans -ön test } & Deney Grubu & 30 & 43.60 & 14.75 & .18 & .01 \\
\hline & Kontrol grubu & 28 & 37.93 & 15.64 & .94 & .15 \\
\hline \multirow[t]{2}{*}{ Genel performans-son test } & Deney Grubu & 30 & 53.43 & 10.96 & .19 & .00 \\
\hline & Kontrol grubu & 28 & 46.39 & 12.43 & .83 & .00 \\
\hline \multirow[t]{2}{*}{ Akademik Motivasyon Ölçeği- ön test } & Deney Grubu & 30 & 115.90 & 24.24 & .13 & .20 \\
\hline & Kontrol grubu & 28 & 110.00 & 18.74 & .93 & .08 \\
\hline \multirow[t]{2}{*}{ Akademik Motivasyon Ölçeği-son test } & Deney Grubu & 30 & 118.70 & 29.35 & .07 & .20 \\
\hline & Kontrol grubu & 28 & 110.80 & 17.49 & .95 & .23 \\
\hline
\end{tabular}

Analiz Performans Testinin değerlendirilmesinde Analiz Performans Testi Rubriği kullanılmıştır.

\section{Tablo 5.}

\section{Analiz Performans Testi Rubriği}

\begin{tabular}{|c|c|}
\hline Cevap türü & Ölçütler \\
\hline Doğru cevap ( 3 puan) & $\begin{array}{l}\text { işlem basamaklarının doğru uygulanması ve sonucun doğru bulunması ya da grafik } \\
\text { yorumunun doğru yapılması }\end{array}$ \\
\hline Kismi cevap ( 2 puan) & $\begin{array}{l}\text { işlem basamaklarında, sonucun bulunmasında veya grafik yorumlamada doğru, } \\
\text { yanlış ve eksik kısımların bulunması }\end{array}$ \\
\hline Yanlış cevap ( 1 puan) & $\begin{array}{l}\text { işlem basamaklarının yanlış uygulanması, sonucun bulunamaması ya da yanlış } \\
\text { bulunması veya grafik yorumlamanın yanlış yapılması }\end{array}$ \\
\hline Cevap yok (0 puan) & sorunun cevap olarak yazılması ya da boş bırakılması \\
\hline
\end{tabular}

Analiz Performans Testinden elde edilen cebirsel, geometrik ve genel performans verileri grupların en az birinde normal dağılım göstermediğinden; deney ve kontrol gruplarının ön test ve son test puan ortalamaları arasında istatistiksel olarak anlamlı bir fark olup olmadığını belirlemek için Mann Whitney U ve grupların her birinin ön test-son test puanları arasında istatistiksel olarak anlamlı bir fark olup olmadığını belirlemek için Wilcoxon İşaretli Sıralar testinden yararlanılmıştır.

Normallik testlerin yapılmasıyla deney ve kontrol gruplarına ön test ve son test olarak uygulanan Akademik Motivasyon Ölçeğinden elde edilen verilerin normal dağılım gösterdiği ve iki grubun varyansları arasında istatistiksel olarak anlamlı fark olmadığı görülmüştür. Böylece parametrik testlerin şartları sağlandığından, deney ile kontrol grubunun Akademik Motivasyon Ölçeğinden elde edilen ön test ve son test puan 
ortalamaları arasında istatistiksel olarak anlamlı bir fark olup olmadığını belirlemek için bağımsız gruplar ttestinden ve grupların her birinin ön test-son test puanları arasında istatistiksel olarak anlamlı bir fark olup olmadığını belirlemek için bağımlı gruplar t-testinden yararlanılmıştır.

\section{Etik}

“GeoGebra Destekli Öğretimin İlköğretim Matematik Öğretmeni Adaylarının Akademik Performanslarına ve Motivasyonlarına Etkisi: Diziler Örneği (The Effect of GeoGebra Assisted Instruction on Preservice Elementary Mathematics Teachers' Academic Performance and Motivation: A Sample of Sequences)" başlıklı çalışmada bilimsel araştırma ve yayın etiği ilkelerine uyulduğunu herhangi bir etik ihlalle karşılaşılması durumunda Necmettin Erbakan Üniversitesi Ereğli Eğitim Fakültesi Dergisi'nin hiçbir sorumluluğunun olmadığını, tüm sorumluluğun yazara ait olduğunu taahhüt ederim.

\section{BULGULAR}

\section{Araştırma Sorusuna İlişskin Bulgular}

Araştırmanın birinci sorusu "Analiz dersinde GeoGebra destekli öğretimin uygulandığı deney grubundaki öğretmen adaylarının, Analiz Performans Testinden ve Akademik Motivasyon Ölçeğinden aldıkları ön testson test puanları arasında anlamlı bir farklılık var mıdır?" şeklinde olup bu probleme cevap bulmak için sırasıyla Wilcoxon İşaretli Sıralar Testinden ve bağımlı gruplar t-testinden yararlanılmıştır.

Deney grubundaki öğretmen adaylarının Analiz Performans Testinden aldıkları cebirsel, geometrik ve genel performans ön test-son test puanlarının Wilcoxon İşaretli Sıralar testi ile yapılan analizlerine ilişkin istatistikler tablo 6'da sunulmuştur.

\section{Tablo 6.}

Deney Grubundaki Öğretmen adaylarının Cebirsel, Geometrik ve Genel Performans Ön Test-Son Test Puanlarına İlişkin Wilcoxon Işsaretli Sıralar Testi Sonuçları

\begin{tabular}{lllllll}
\hline Deney grubu & $\begin{array}{l}\text { Sontest-Öntest } \\
\text { Ölçümü }\end{array}$ & $\mathrm{n}$ & $\begin{array}{l}\text { Sıra } \\
\text { Ortalamas1 }\end{array}$ & $\begin{array}{l}\text { Sira } \\
\text { Toplam1 }\end{array}$ & $\mathrm{z}$ & $\mathrm{p}$ \\
\hline Cebirsel performans & Negatif Sıralar & 3 & 9.50 & 28.50 & -3.62 & .00 \\
& Pozitif Sıralar & 22 & 13.48 & 296.50 & & \\
& Fark Olmayan & 5 & & & & \\
\hline Geometrik performans & Negatif Siralar & 5 & 11.60 & 58 & -2.81 & .00 \\
& Pozitif Siralar & 20 & 13.35 & 267 & & \\
& Fark Olmayan & 5 & & & & \\
\hline Genel performans & Negatif Siralar & 2 & 17.75 & 35.50 & -3.55 & .00 \\
& Pozitif Sıralar & 24 & 13.15 & 315.50 & & \\
\hline & Fark Olmayan & 4 & & & & \\
\hline
\end{tabular}

Tablo 6 incelendiğinde; deney grubundaki öğretmen adaylarının Analiz Performans Testinden aldıkları cebirsel, geometrik ve genel performans ön test ve son test puanları karşılaştırıldı̆̆ında sergilenen performansın anlamlı bir şekilde farklılaştığı görülmektedir ( $\mathrm{z}=-3.62 ; \mathrm{z}=-2.81 ; \mathrm{z}=-3.55 ; p<.05)$. Bu durum GeoGebra destekli öğretim ile gerçekleştirilen analiz derslerinin öğretmen adaylarının cebirsel, geometrik ve genel performanslarını olumlu yönde etkilediğini göstermektedir.

Deney grubundaki öğretmen adaylarının Akademik Motivasyon Ölçeğinden aldıkları ön test-son test puanlarının bağımlı gruplar t-testi ile yapılan analizlerine ilişkin istatistikler tablo 7'de sunulmuştur. 
Tablo 7.

Deney Grubundaki Öğretmen Adaylarının Akademik Motivasyon Ölçeği Ön Test-Son Test Puanlarına İlişkin Bă̆ımlı Gruplar t-Testi Sonuçları

\begin{tabular}{llllll}
\hline Ölçüm & $\mathrm{n}$ & $\bar{x}$ & $S_{x}$ & $\mathrm{t}$ & $\mathrm{p}$ \\
\hline Öntest & 30 & 115.9 & 24.24 & -0.81 & .42 \\
Sontest & 30 & 118.7 & 29.35 & & \\
\hline
\end{tabular}

Tablo 7 incelendiğinde; deney grubundaki öğretmen adaylarının Akademik Motivasyon Ölçeğinden aldıkları ön test ve son test puanları karşılaştırıldığında istatistiksel olarak anlamlı bir fark olmadığı görülmüştür ( $\mathrm{t}=-0.81 ; p>.05)$. Bu durum, GeoGebra destekli öğretim ile gerçekleştirilen analiz derslerinin öğretmen adaylarının akademik motivasyonlarını etkilemediğini göstermektedir.

\section{Araştırma Sorusuna İliş̧kin Bulgular}

Araştırmanın diğer bir sorusu “Analiz dersinde geleneksel öğretim yapılan kontrol grubundaki öğretmen adaylarının, Analiz Performans Testinden ve Akademik Motivasyon Ölçeğinden aldıkları ön test-son test puanları arasında anlamlı bir farklılık var mıdır?" şeklinde olup bu probleme cevap bulmak için sırasıyla Wilcoxon İşaretli Sıralar testinden ve bağımlı gruplar t-testinden yararlanılmıştır.

Kontrol grubundaki öğretmen adaylarının Analiz Performans Testinden aldıkları ön test-son test puanlarının Wilcoxon İşaretli Sıralar testi ile yapılan analizlerine ilişkin istatistikler tablo 8'de sunulmuştur.

\section{Tablo 8.}

Kontrol Grubundaki Öğretmen Adaylarının Cebirsel, Geometrik ve Genel Performans Ön Test-Son Test Puanlarına İlişkin Wilcoxon Işsaretli Siralar Testi Sonuçları

\begin{tabular}{|c|c|c|c|c|c|c|}
\hline Kontrol grubu & $\begin{array}{l}\text { Sontest-Öntest } \\
\text { Ölçümü }\end{array}$ & $\mathrm{n}$ & $\begin{array}{l}\text { Sira } \\
\text { Ortalamas1 }\end{array}$ & $\begin{array}{l}\text { Sira } \\
\text { Toplamı }\end{array}$ & $\mathrm{z}$ & $\mathrm{p}$ \\
\hline \multirow[t]{3}{*}{ Cebirsel performans } & Negatif Siralar & 2 & 7.5 & 15 & -3.74 & .00 \\
\hline & Pozitif Siralar & 21 & 12.43 & 261 & & \\
\hline & Fark Olmayan & 5 & & & & \\
\hline \multirow[t]{3}{*}{ Geometrik performans } & Negatif Siralar & 10 & 8.65 & 86.50 & -1.00 & .31 \\
\hline & Pozitif Sıralar & 11 & 13.14 & 144.50 & & \\
\hline & Fark Olmayan & 7 & & & & \\
\hline \multirow[t]{3}{*}{ Genel performans } & Negatif Siralar & 5 & 10.60 & 53.00 & -2.58 & .10 \\
\hline & Pozitif Siralar & 18 & 12.39 & 223.00 & & \\
\hline & Fark Olmayan & 5 & & & & \\
\hline
\end{tabular}

Tablo 8 incelendiğinde; kontrol grubundaki öğretmen adaylarının Analiz Performans Testinden aldıkları geometrik performans ve genel performans ön test ve son test puanları karşılaştırıldığında istatistiksel olarak anlamlı bir fark olmadığı $(\mathrm{z}=-1.00 ; \mathrm{z}=-2.58 ; p>.05)$ ancak cebirsel performans ön test ve son test puanları karşılaştırıldığında sergilenen performansın istatistiksel olarak anlamlı bir şekilde farklılaştığı ( $\mathrm{z}=-3.74$; $p<.05)$ görülmektedir. $\mathrm{Bu}$ durum geleneksel öğretim ile gerçekleştirilen analiz derslerinin geometrik performans1 etkilemediğini ancak cebirsel performansı olumlu yönde etkilediğini göstermektedir.

Kontrol grubundaki öğretmen adaylarının Akademik Motivasyon Ölçeğinden aldıkları ön test-son test puanlarının bağımlı gruplar t-testi ile yapılan analizlerine ilişkin istatistikler tablo 9'da sunulmuştur. 
Tablo 9.

Kontrol Grubundaki Öğretmen Adaylarının Akademik Motivasyon Ölçeği Ön Test-Son Test Puanlarına İlişkin Bağımlı Gruplar t- Testi Sonuçları

\begin{tabular}{llllll}
\hline Ölçüm & $\mathrm{n}$ & $\bar{x}$ & $S_{x}$ & $\mathrm{t}$ & $\mathrm{p}$ \\
\hline Öntest & 28 & 110 & 18.74 & -0.44 & .65 \\
\hline Sontest & 28 & 110.8 & 17.49 & & \\
\hline
\end{tabular}

Tablo 9 incelendiğinde; kontrol grubundaki öğretmen adaylarının Akademik Motivasyon Ölçeğinden aldıkları ön test ve son test puanları arasında anlamlı bir fark olmadığ 1 ( $\mathrm{t}=-0.44 ; p>.05)$ görülmüştür. $\mathrm{Bu}$ durum geleneksel öğretim ile gerçekleştirilen analiz derslerinin akademik motivasyonu etkilemediğini göstermektedir.

\section{Araştırma Sorusuna İliş̧kin Bulgular}

Araştırmanın diğer bir sorusu "Analiz dersinde GeoGebra destekli öğretimin uygulandığı deney ile geleneksel öğretim yapılan kontrol grubundaki öğretmen adaylarının, Analiz performans Testinden ve Akademik Motivasyon Ölçeğinden aldıkları son test puan ortalamaları arasında anlamlı bir farklılık var mıdır?" şeklinde olup bu probleme cevap bulmak için Mann Whitney U testinden ve bağımsız gruplar ttestinden yararlanılmıştır.

Deney ve kontrol gruplarındaki öğretmen adaylarının Analiz Performans Testinden aldıkları son test puan ortalamalarının Mann Whitney U testi ile yapılan analizlerine ilişkin istatistikler tablo 10' da sunulmuştur.

Tablo 10.

Deney ve Kontrol Gruplarındaki Öğretmen Adaylarının Cebirsel, Geometrik ve Genel Performans Son Test Puanlarına İlişkin Mann Whitney U Testi Sonuçları

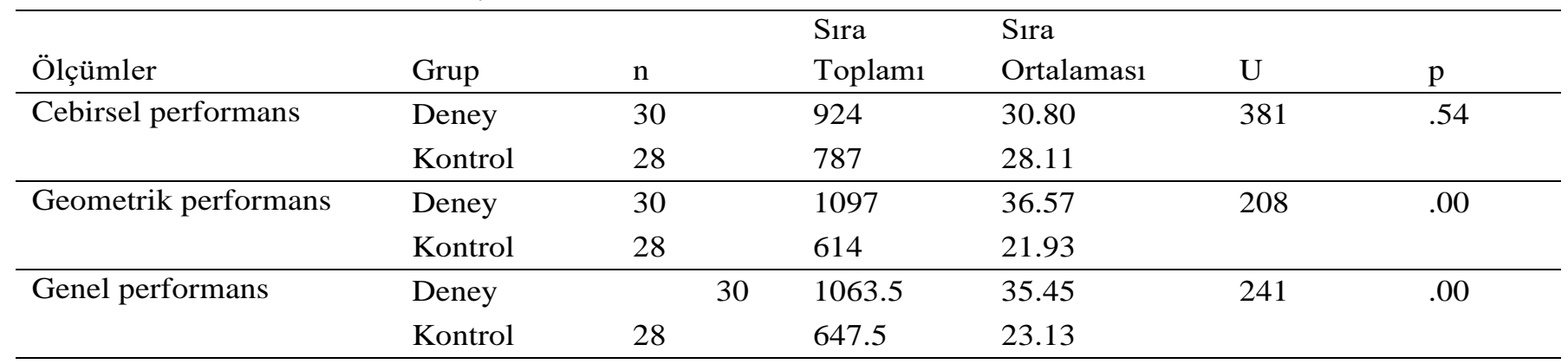

Tablo 10 incelendiğinde; deney ve kontrol gruplarındaki öğretmen adaylarının cebirsel performans son test puan ortalamaları arasında istatistiksel olarak anlamlı bir fark olmadığ $(\mathrm{U}=381 ; p>.05)$ ancak geometrik ve genel performans son test puan ortalamaları arasında deney grubu lehine istatistiksel olarak anlamlı bir farklıl1k olduğu $(U=208 ; \quad U=241 ; p<.05)$ görülmektedir. $\mathrm{Bu}$ durum GeoGebra destekli öğretim ile gerçekleştirilen analiz derslerinin öğretmen adaylarının geometrik ve genel performansını olumlu yönde etkilediğini göstermektedir. Ayrıca deney ve kontrol gruplarında cebirsel performans bağlamında istatistiksel olarak anlamlı bir farklılık oluşmadığı görülmektedir. Bu durum GeoGebra destekli öğretim ya da geleneksel öğretim ile gerçekleştirilen analiz derslerinin öğretmen adaylarının cebirsel performansına ilişkin bir farklılık oluşturmadığını göstermektedir.

Deney ve kontrol gruplarındaki öğretmen adaylarının Akademik Motivasyon Ölçeğinden aldıkları son test puanlarının bağımsız gruplar $\mathrm{t}$ testi ile yapılan analizlerine ilişkin istatistikler tablo 11 ' de sunulmuştur. 
Tablo 11.

Deney ve Kontrol Gruplarındaki Öğretmen Adaylarının Akademik Motivasyon Ölçeği Son Test Puanlarına İlişkin Bă̆ımsız Gruplar t-Testi Sonuçları

\begin{tabular}{lllllll}
\hline Grup & $\mathrm{n}$ & $\bar{x}$ & $S_{x}$ & $\mathrm{Sd}$ & $\mathrm{t}$ & $\mathrm{p}$ \\
\hline Deney & 30 & 118.7 & 29.35 & 56 & 1.23 & .22 \\
Kontrol & 28 & 110.8 & 17.49 & & & \\
\hline
\end{tabular}

Tablo 11 incelendiğinde; deney ve kontrol gruplarındaki öğretmen adaylarının Akademik Motivasyon Ölçeği son test puan ortalamaları arasında istatistiksel olarak anlamlı bir fark olmadığı görülmüştür ( $\mathrm{t}=1.23$; $p>.05)$. Bu durum, GeoGebra destekli öğretim ya da geleneksel öğretim ile gerçekleştirilen analiz derslerinin öğretmen adaylarının akademik motivasyonları açısından bir farklılık oluşturmadığını göstermektedir

\section{TARTIŞMA ve SONUÇ}

$\mathrm{Bu}$ araştırma, analiz dersinde uygulanan GeoGebra destekli öğretimin, öğretmen adaylarının akademik performanslarına ve motivasyonlarına etkisinin olup olmadığını belirlemek amacıyla gerçekleştirilmiştir.

Araştırma sonucunda, diziler konusunun öğretiminin tamamlanmasının ardından uygulanan Analiz Performans Testi sonuçlarına göre, deney ve kontrol gruplarının son test puan ortalamaları arasında deney grubu lehine istatistiksel olarak anlamlı bir fark olduğu tespit edilmiştir. Bu bulgu, GeoGebra destekli öğretimin öğretmen adaylarının akademik performanslarını geleneksel öğretime göre daha fazla geliştirdiği sonucunu ortaya koymaktadır. Literatürde geleneksel öğretimle gerçekleştirilen matematik öğretimin yeterli olmadığını GeoGebra destekli öğretimin öğrenme sürecine olumlu etkilerinin olduğunu (Dikovic, 2009; Shadaan ve Leong, 2013), akademik performans düzeyini artırdığını (Saha, Ayub ve Tarmizi, 2010; GómezChacón ve Escribano, 2011; Zengin, Furkan ve Kutluca, 2012; Güven ve Yılmaz, 2012; Tatar, Kağımanlı ve Akkaya, 2014; Kan, 2014; Aydos,2015; Acar, 2015; Bhagat ve Chang, 2015; Ünlütürk-Akçakın, 2016; Kepçeoğlu ve Yavuz, 2017; Ocal, 2017; Çekmez ve Baki, 2018) ve öğrenmeyi kolaylaştırdığını (Taş, 2010; Reis ve Özdemir, 2010) gösteren araştırmalar bulunmaktadır. Ayrıca, araştırmanın bulguları, GeoGebra destekli öğretimin cebirsel performans bağlamında gruplar arasında bir farklılık oluşturmadığını ancak geometrik performansı ve genel performansı artırdığını göstermektedir. Bu durumun, öğretmen adaylarının pasif olduğu geleneksel öğretimin daha çok cebirsel temsil temelinde gerçekleşmesinden, öğretim sürecinde kavramların farklı temsillerinin, materyallerin çok fazla kullanılmamasından, kaynaklanmış olabileceği düşünülmektedir. Diğer taraftan, GeoGebra destekli öğretim, zamanın verimli bir şekilde kullanılmasından dolayı istenilen amaçlar için uğraşılmasına daha çok imkân tanımakta (Aktümen, Yıldız, Horzum ve Ceylan, 2011) ve kavramların temsilleri arasında ilişkilendirme imkânı sağlamaktadır (Kan, 2014). Bundan dolayı öğretmen adayları, kavramların cebirsel ifadeleriyle birlikte grafik yorumlarını anlamlandırmış olabilir. Ayrıca yapılan analizlerde geleneksel öğretim ve GeoGebra destekli öğretim sürecinin cebirsel performansı olumlu yönde etkilediği tespit edilmiştir. Nitekim, lisans düzeyinde, farklı çözüm yollarını kullanma eğiliminin incelendiği bir araştırmada, cebirsel yorumlama yapılması beklenen sorularda, geometrik yorumlama yapılması beklenen sorulara göre daha yüksek düzeyde performans sergilendiği sonucuna varılmıştır (Delice, Aydın ve Kardeş-Birinci, 2014). Bu durumun, öğretmen adaylarının, öğrenim hayatları boyunca ölçme ve değerlendirmelerde daha çok işleme dayalı tekniklerle çözümü bulabilecekleri sorularla değerlendirilmesinden (Aydın ve Delice, 2008) ve grafik temsiline göre cebirsel temsille ifade edilen sorulara daha çok aşina olmalarından kaynaklanmış olabileceği düşünülmektedir.

Araştırma sonucunda, uygulanan Akademik Motivasyon Ölçeğinden elde edilen sonuçlara göre deney grubunun son test puan ortalamalarının, kontrol grubunun son test puan ortalamalarından daha yüksek olduğu ancak bu ortalamalar arasındaki farklılı̆̆ın istatistiksel olarak anlamlı olmadığı belirlenmiştir. Ayrıca, her iki gruptaki öğretmen adaylarının motivasyon ölçeği ön test-son test puanları arasında anlamlı bir artış olmadığı tespit edilmiştir. Bu bulgular, analiz dersinde uygulanan GeoGebra destekli öğretimin ve 
geleneksel öğretimin öğretmen adaylarının akademik motivasyonlarını etkilemedi ği sonucunu ortaya koymaktadır. Alan yazın incelendiğinde, GeoGebra destekli öğretimin duyuşsal becerilerden kaygıyı (Sümen- Özçakır, 2013), tutumu (Şataf, 2010; Zengin, 2011) ve akademik motivasyonu (Ünlütürk-Akçakın, 2016) değiştirmede etkili olmadığını gösteren araştırmalar bulunmaktadır. Diğer taraftan teknoloji destekli öğretimin motivasyonu olumlu yönde desteklediğini gösteren (Papastergiou, 2009; Choi, 2010; Akçayır, 2011; Wah, 2015; Kutluca ve Zengin, 2011) nicel ve nitel araştırmalar bulunmaktadır. Duyuşsal özellikleri ölçen ölçekler, bireylerin anlık duygularını, düşüncelerini ve hislerini değerlendirmeye yönelik (Karagüven, 2012) olduğundan ve çalışmalarda kullanılan ölçekler birbirinden farklı alt boyutlardan oluştuğundan farklı sonuçlar elde edilmiş olabilir. Bireyin duyuşsal alandaki öğrenmeleri; yetenekleri ve çevresi arasındaki etkileşimin ürünü olsa da inanç, tutum gibi duyuşsal özellikler kalıplaşmış, değiştirilmesi zor, bazı durumlarda öğretim üyesinin ya da öğretim sürecinin olumlu etkilerini aşabilen özelliklerdir (Tekin, 2003). Bununla birlikte, duyuşsal alana ilişkin öğrenmeler bilişsel öğrenmelere göre daha uzun zamanda oluşmaktadır ve bazen öğretim sürecinin tamamlanmasının ardından ortaya çıkmaktadır. Bu çalışma ise uzun olarak nitelendirilemeyecek bir zaman aralığında gerçekleştiğinden, duyuşsal alanda değişim olsa da bunun belirlenmesi zordur (Balaban-Sal1, 2006). Eldeki çalışmada, uygulama sonucunda deney grubundaki öğretmen adaylarının akademik performanslarının olumlu yönde farklılaşmasına ve motivasyon değişkeni ile akademik performans arasında güçlü bir ilişki olmasına (Neisi ve Yamini, 2010) rağmen, akademik anlamda davranışı ortaya çıkarmak için harekete geçiren isteklilik halinin yansıması olan akademik motivasyon düzeylerinin değişmemesi dikkat çekici bir sonuçtur. Bu durum ayrıca araştırılması gereken bir husus olmakla birlikte, bu sonucun cinsiyet, sınıf düzeyi, aktif katılım, tutum (Williams ve Williams, 2011), öğretim üyesi gibi öğretim sürecindeki motivasyonu etkileyen diğer değişkenlerden kaynaklanmış olabileceği düşünülmektedir. Motivasyon üzerinde son derece etkili değişkenlerden biri de öz yeterliliktir (Gürlen, 2011). Öz yeterliliği yüksek olan bireylerin herhangi bir düşüncelerini denemekten korkmadıkları belirlenmiştir (Senemoğlu, 2015). Böylece öz yeterliliği düşük olan bireylerde davranışı ortaya koymak için isteklilik hali oluşmayabilir. GeoGebra destekli öğretim sürecinde, duyuşsal özelliklerden biri olan, akademik motivasyonun bu nedenlerden dolayı farklılaşmamış olabileceği düşünülmektedir.

\section{ÖNERILER}

Literatürde limit değerinin fonksiyonda yerine koyarak elde edildiğine, limit değerine asla ulaşılamayacağına ve fonksiyonun tanım kümesine (Özmantar ve Yeşildere, 2008) ilişkin yanılgılara rastlanmaktadır. Dizilerle ilgili araştırmalarda benzer yanılgılara rastlanmakla birlikte bu yanılgıların sonsuzluk kavramının anlaşılmamasından (Roh, 2008) kaynaklandığı ve bu durumun limit kavramının, fonksiyon ya da dizinin değeri ile karıştırılmasına neden olduğu vurgulanmaktadır (Cottrill ve ark., 1996). Öğrencilerin; düzeltilmesi zor olan bu kavram yanılgılarını (Williams, 1991) ortadan kaldırmak, kavram imajlarını zenginleştirmek ve formal tanımı anlamlandırmalarını sağlamak için görselleştirmede, kavramları ilişkilendirmede, soyut yapıyı somutlaştırmada etkili olan geleneksel öğretimden farklı yöntem ve tekniklerden yararlanılabilir.

GeoGebra destekli uygulamalar, öğretmen adaylarının tanımla uyumlu imajlar geliştirmesini, tamamlanmamış imajlarını tamamlamalarını ve bununla birlikte tanımla örtüşen imajlarını kullanarak doğru cevabı bulmalarını sağlamaktadır (Öner, 2013). GeoGebra yazılımından yararlanarak geliştirilen materyallerin, limit kavramına ilişkin kavram imajına etkilerinin araştııılması önerilebilir.

Kavramların cebirsel ifadesini, grafiğini; cebir ve grafik penceresinde aynı ara yüzde görebilme imkânı sunan GeoGebra yazılımından yararlanarak öğrenciler, kavramların sembolik ve görsel temsilleri arasında ilişki kurmakta ve böylece daha iyi performans göstermektedir (Dikovic, 2009). Bununla birlikte bu araştırmada öğretim sürecine olumlu yansımaları tespit edilen GeoGebra destekli öğretimin daha etkili olabilmesi için, yapılacak çalışmalarda araştırma süresinin daha uzun tutulması ve analiz dersinin yanı sıra diğer alan derslerinde bu yazılımdan yararlanılması önerilebilir. 
Lisans düzeyindeki alan derslerinin içeriğinin yoğun ve anlaşılması zor bilgilerden oluşmasından ve bu bilgilerin öğretmenlik mesleğini yürütürken kullanılmayacağının düşünülmesinden dolayı öğretim sürecinde kazanılması beklenen beceriler gereksiz (Kaymakcı, Keskin ve Çimen, 2018) ve ulaşılması zor olarak nitelendirmektedir. Öğretim sürecindeki bu olumsuz düşünceleri ortadan kaldırmak, bilişsel becerilerle birlikte duyuşsal beceri düzeylerini geliştirmek için bu değişkenleri etkileyen değişkenler ve aralarındaki ilişki araştırılabilir. Bu araştırmada, GeoGebra destekli öğretiminin akademik performansı olumlu yönde etkilediği ancak motivasyon düzeyini geliştiremediği tespit edilmiştir. Nitekim literatürde sınıf seviyesi arttıkça motivasyonun azaldığına ilişkin çalışmalar (Sıcak ve Başören, 2015; Çakır, 2006) bulunmaktadır. $\mathrm{Bu}$ durumun nedenlerinin ve öğretim sürecinde geliştirilmek istenen en önemli değişkenlerden biri olan motivasyona (Williams ve Williams, 2011) etki eden diğer değişkenlerin belirlenmesine yönelik araştırmalar yapılabilir.

\section{KAYNAKÇA}

Acar, H. (2015). Üstel ve logaritmik fonksiyonlar konusunun dinamik geometri yazılımı Geogebra ile ögretiminin ögrenci başarısına etkisi. Yayımlanmamış yüksek lisans tezi, Fen Bilimleri Enstitüsü, Uşak.

Akarsu, B. (2016). Hipotezlerin, değişkenlerin ve örneklemin belirlenmesi. M. Metin (Ed.), Ĕgitimde Bilimsel Araştırma Yöntemleri (3. Bask1, s.21-43). Pegem Akademi.

Akbaba, S. (2006). Eğitimde motivasyon. Atatürk Üniversitesi Kazım Karabekir Eğitim Fakültesi Dergisi, (13), 343-361.

Akçayır, M. (2011). Akıllı tahta kullanılarak işlenen matematik dersinin sınıf öğretmenliği birinci sınıf ögrencilerinin başarı, tutum ve motivasyonlarına etkisi. Yayınlanmamış yüksek lisans tezi, Gazi Üniversitesi Eğitim Bilimleri Enstitüsü, Ankara.

Aktümen, M., Yıldız, A., Horzum, T. ve Ceylan, T. (2011). İlköğretim matematik öğretmenlerinin GeoGebra yazılımının derslerde uygulanabilirliği hakkındaki görüşleri. Türk Bilgisayar ve Matematik Ĕgitimi Dergisi, 2(2).

Aydın, E. ve Delice, A. (2008). Ölçme ve değerlendirmeye kavram yanılgıları perspektifinden bir bakış M.F. Özmantar, E. Bingölbali ve H. Akkoç (Ed). Matematiksel Kavram Yanılgıları ve Çözüm Önerileri. Pegem Yayıncilık

Aydos, M. (2015). The impact of teaching mathematics with geogebra on the conceptual understanding of limits and continuity: The case of Turkish gifted and talented students. Doctoral dissertation, Bilkent University, Ankara .

Bacanl1, H. ve Sahinkaya, O. (2011). The adaptation study of academic motivation scale into Turkish. Procedia-Social and Behavioral Sciences, 12, 562-567.

Balaban Salı, J. (2006). Tutumların Öğretimi. A. Şimşek (Ed.), İçerik Türlerine Dayalı Öğretim (ss. 133162). Nobel Yayın Dağıtım.

Barçın, H (2019). Matematik dersi dönüşüm geometrisi konusunun GeoGebra yazılımı ile anlatımının ögrencilerin matematik başarısına, kaygısına ve tutumuna etkisi. Yüksek Lisans Tezi, Necmettin Erbakan Üniversitesi, Konya.

Bayazit, İ., ve Aksoy, Y. (2013). Fonksiyon kavramı: epistemolojisi, algı türleri ve zihinsel gelişimi. Erciyes Üniversitesi Fen Bilimleri Enstitüsü Fen Bilimleri Dergisi, 29(1), 1-9.

Bezuidenhout, J. (2001). Limits and continuity: some conceptions of first-year students. International journal of mathematical education in science and technology, 32(4), 487-500.

Bhagat, K. K., \& Chang, C. Y. (2015). Incorporating GeoGebra into Geometry learning-A lesson from India. Eurasia Journal of Mathematics, Science \& Technology Education, 11(1), 77-86.

Burn, B. (2005). The vice: Some historically inspired and proof-generated steps to limits of sequences. Educational Studies in Mathematics, 60(3), 269-295.

Büyükköroğlu, T., Düzce, S. A., Çetin, N., Mahir, N., Deniz, A. \& Üreyen, M. (2006). The Effect of Computers on Teaching the Limit Concept, International Journal for Mathematics Teaching and Learning(May 2006).

Can, A. (2016). SPSS ile bilimsel araştırma sürecinde veri analizi. Pegem Akademi. 
Ceylan, T. (2012). Geogebra yazılımı ortamında ilköğretim matematik ögretmen adaylarının geometrik ispat biçimlerinin incelenmesi. Yüksek Lisans Tezi, Ankara Üniversitesi Eğitim Bilimleri Enstitüsü, Ankara.

Chappell, K. K., \& Kilpatrick, K. (2003). Effects of concept-based instruction on students' conceptual understanding and procedural knowledge of calculus. Primus 13(1), 17-37.

Cornu, B. (1991). Limits. In D. Tall (Ed.), Advanced mathematical thinking (pp. 25-41). Dordrecht: Kluwer Academic Publisher.

Cottrill, J., Dubinsky, E., Nichols, D., Schwingendorf, K., Thomas, K., \& Vidakovic, D. (1996). Understanding the limit concept: Beginning with a coordinated process scheme. Journal of Mathematical Behavior, 15(2), 167-192.

Çakır, E. (2006). Anadolu öğretmen lisesinde okuyan öğrencilerin depresyon ve motivasyon düzeyleri. Yayımlanmamış Yüksek Lisans Tezi, Sakarya Üniversitesi, Sakarya.

Çekmez, E. ve Baki, A. (2018). Dinamik Matematik Yazılımı Kullanımının Öğrencilerin Türev Kavramının Geometrik Boyutuna Yönelik Anlamalarına Etkisi. Türk Bilgisayar ve Matematik Eğitimi Dergisi, 10(1), 30-58.

Çetin, N. (2009). The performance of undergraduate students in the limit concept. International Journal of Mathematical Education in Science and Technology, 40(3), 323-330.

Choi, K. S. (2010). Motivating students in learning mathematics with GeoGebra. Annals Computer Science Series, 8(2), 65-76

Çirişoğlu, İ. İ. ve Kaçar, A. (2019). Rn Uzayındaki Temel Topolojik Kavramların Öğretiminde Geogebra Kullanımının Etkisi. Başkent University Journal of Education, 6(2), 313-327.

Danış, M. Z. (2006). Davranış bilimlerinde ekolojik sistem yaklaşımı. Sosyal Politika Çalışmaları Dergisi, 9(9), 45-54.

Davis, R.B., \& Vinner, S., (1986). The Notion of Limit: Some Seemingly Unavoidable Misconception Stages. Journal of Mathematical Behavior,5(3),281-303.

Delice, A., Aydın, E., \& Birinci, D. K. (2014). An Investigation of Pre-Services Mathematics Teachers' Performances on Systems of Linear Equations within the Context of Self-Efficacy Levels. International Journal of Educational Studies in Mathematics, 1(2), 19-33.

Dikovic, L. (2009). Applications GeoGebra into teaching some topics of mathematics at the college level. Computer Science and Information Systems, 6(2), 191-203.

Doğan, N. (2010). Bilgisayar destekli istatistik öğretiminin başarıya ve istatistiğe karşı tutuma etkisi. Ĕgitim ve Bilim, 34(154), 3-16.

Dubinsky, E., \& Harel, G. (1992). The nature of the process conception of function. The Concept of Function: Aspects of Epistemology and Pedagogy, 25, 85-106.

Edwards, J. A., \& Jones, K. (2006). Linking geometry and algebra with GeoGebra. Mathematics Teaching, 194, 28-30.

Elliot, A. J., \& Thrash, T. M. (2001). Achievement goals and the hierarchical model of achievement motivation. Educational Psychology Review, 13(2), 139-156.

Ersoy, E. (2012). Probleme dayal ögrrenme sürecinde üst düzey bilişsel düşünme becerileri ve duyuşsal kazanımlardaki değişim. Doktora tezi, Dokuz Eylül Üniversitesi, Eğitim Bilimleri Enstitüsü, İzmir.

Girard, N. R. (2002). Students' representational approaches to solvingc alculus problems: Examining the role of graphing calculators. Unpublished EdD Thesis, University of Pittsburg, USA.

Gómez-Chacón, I. M., \& Escribano, J. (2011). Teaching geometric locus using GeoGebra. An experience with pre-service teachers. GeoGebra International Journal of Romania (GGIJRO), GeoGebra The New Language For The Third Millennium, 2(1), 209-224.

Gunčaga, J. (2011). GeoGebra in Mathematical Educational Motivation. Annals: Computer Science Series, 9, 75-84.

Gürlen, E. (2011). Probleme dayalı öğrenmenin öğrenme ürünlerine, problem çözme becerilerine,öz-yeterlik alg1 düzeyine etkisi. Hacettepe Üniversitesi Eğitim Fakültesi Dergisi, 40,221-232.

Güven, B. ve Karatas, I. (2003). Dinamik geometri yazılımı cabri ile geometri ögrenme: Öğrenci görüşleri. TOJET: The Turkish Online Journal of Educational Technology, 2(2), 67-78. 
Güven, B. ve Yılmaz, G. K. (2012). Dinamik geometri yazılımı kullanımının sınıf öğretmeni adaylarının dönüşümler konusundaki akademik başarılarına etkisi. Education Sciences, 7(1), 442-452.

Hallet, D. H. (1991). Visualization and calculus reform. In Visualization in teaching and learning mathematics (pp. 121-126). Mathematical Association of America.

Hiçcan, B. (2008). 5E ögrenme döngüsü modeline dayalı öğretim etkinliklerinin ilkögretim 7. sinıf ögrencilerinin matematik dersi birinci dereceden bir bilinmeyenli denklemler konusundaki akademik başarılarına etkisi. Yayınlanmış Yüksek Lisans Tezi, Gazi Üniversitesi, Eğitim Bilimleri Enstitüsü, Ankara.

Hohenwarter, M., \& Jones, K. (2007). Ways of linking geometry and algebra, the case of GeoGebra. Proceedings of the British Society for Research into Learning Mathematics, 27(3), 126-131.

Hughes-Hallett, D., Gleason, A. M., McCallum, W. G. et al. (2008). Calculus: Single variable (5th Edition). New York: Wiley.

Hülya, D. (2019). An Investigation of the Effects of 5E Model Based on Context-Based Instruction Approach on the Attitudes and Perception of Self-Efficacy of Pre-Service Teachers towards the Assessment and Evaluation Course. Kastamonu Education Journal, 27(6), 2547-2558.

Kabaca, T. (2006). Limit kavramının öğretiminde bilgisayar cebiri sistemlerinin etkisi. Yayımlanmamış doktora tezi, Gazi Üniversitesi Eğitim Bilimleri Enstitüsü, Ankara.

Kağızmanlı, T. B., ve Tatar, E. (2012). Matematik öğretmeni adaylarının bilgisayar destekli öğretim hakkındaki görüşleri: Türevin uygulamaları örneği. Kastamonu Eğitim Dergisi, 20(3), 897-912.

Kan, O. (2014). GeoGebra destekli ögretimin lineer cebir dersine ait bazı konularda akademik başarı üzerine etkisi. Yüksek Lisans Tezi, Necmettin Erbakan Üniversitesi, Eğitim Bilimleri Enstitüsü, Konya.

Karagüven, M. (2012). The Adaptation of Academic Motivation Scale to Turkish. Educational Sciences: Theory and Practice, 12(4), 2611-2618.

Kaymakc1, K., Keskin, E. ve Çimen, E. E. (2018). Ortaokul matematik öğretmenlerinin ve ilköğretim matematik öğretmenliği bölümü öğrencilerinin lisans dersleri üzerine görüşleri. Eskişehir Osmangazi Üniversitesi Türk Dünyası Uygulama ve Araştırma Merkezi Ĕ̈itim Dergisi, 3(1), 23-41.

Kepceoğlu, İ. (2010). GeoGebra yazılımıyla limit ve süreklilik öğretiminin ögrretmen adaylarının başarısına ve kavramsal ögrenmelerine etkisi. Yüksek lisans tezi, Marmara Üniversitesi, İstanbul.

Kepçeoğlu, İ. ve Yavuz, İ. (2017). GeoGebra yazılımıyla limit ve süreklilik öğretiminin öğretmen adaylarının başarısına etkisi. Necatibey Eğitim Fakültesi Elektronik Fen ve Matematik Eğitimi Dergisi, 11(1), 21-47.

Kutluca, T. ve Zengin, Y. (2011). Matematik öğretiminde GeoGebra kullanımı hakkında öğrenci görüşlerinin değerlendirilmesi. Dicle Üniversitesi Ziya Gökalp Ĕgitim Fakültesi Dergisi, 17, 160-172.

Lepper, M. R., Corpus, J. H., \& Iyengar, S. S. (2005). Intrinsic and extrinsic motivational orientations in the classroom: Age differences and academic correlates. Journal of Educational Psychology, 97(2), 184196.

Lu, Y. W. A. (2008). English and Taiwaneses upper secondary teachers' approaches to the use of GeoGebra. Acta Scientiae, 10(2), 38-56.

Mamona-Downs, J. (2001). Letting the intuitive bear on the formal; a didactical approach for the understanding of the limit of a sequence. Educational Studies in Mathematics, 48(2-3), 259-288.

Matuga, J. M. (2009). Self-regulation, goal orientation, and academic achievement of secondary students in online university courses. Journal of Educational Technology \& Society, 12(3), 4-11.

Özmen, H. (2016). Nicel Araştırma Yaklaşımına Dayalı Yöntemler. M. Metin (Ed.), Eğitimde Bilimsel Araştırma Yöntemleri (3. Bask1, s.44-76). Pegem Akademi.

Milli Eğitim Bakanlığı [MEB] (2018). Ortaöğretim Matematik (9-12.sınıflar) Dersi Öğretim Programı, Ankara. 12.03.2020 tarihinde http://mufredat.meb.gov.tr/Dosyalar/201821102727101OGM\%20MATEMAT\%C4\%B0K\%20PRG\%2020.01.2018.pdf adresinden erişildi.

Monaghan, J. (1991). Problems with the language of limits. For The Learning Of Mathematics, 11(3), 2024.

Moru, E. K. (2009). Epistemological obstacles in coming to understand the limit of a function at 
undergraduate level: A case from the National University of Lesotho. International Journal of Science and Mathematics Education, 7(3), 431-454.

Navarro, M., \& Carreras, P. (2006). Constructing a concept image of convergence of sequences in the van Hiele framework. Research in Collegiate Mathematics Education, VI, 61-98.

Neisi, S., \& Yamini, M. (2010). Relationshıp between self-esteem, achievement motivation, flca, and efl learners'academic performance. Journal of Education and Psychology, 4(2),153-166.

Ocal, M. F. (2017). The effect of geogebra on students' conceptual and procedural knowledge: The case of applications of derivative. Higher Education Studies, 7(2), 67-78.

Öner, A. (2013). Bilgisayar destekli ögretimin ilköğretim matematik ögretmen adaylarının trigonometrik fonksiyonların periyotlarlyla ilgili kavram imajlarına etkisi. Yüksek Lisans Tezi, Necmettin Erbakan Üniversitesi, Eğitim Bilimleri Enstitüsü, Konya.

Özmantar, F. ve Yeşildere, S. (2008). Limit ve Süreklilik Konularında Kavram Yanılgıları ve Çözüm Arayışları. M.F. Özmantar, E. Bingölbali ve H. Akkoç (Ed). Matematiksel Kavram Yanılgıları ve Çözüm Önerileri. Pegem Yayınc1lık.

Sümen, Ö. Ö. (2013). GeoGebra yazılımı ile simetri konusunun öğretiminin matematik başarısı ve kaygısına etkisi. Yayımlanmamış Yüksek Lisans Tezi, Ondokuz Mayıs Üniversitesi, Eğitim Bilimleri Enstitüsü, Samsun.

Parks, V. W. (1996). Impact of a laboratory approach supported by Mathematica on the conceptualization of limit in a first calculus course (computer algebra system). (Georgia State University, 1995). Dissertation Abstracts International, 56(10), 3872.

Papastergiou, M. (2009). Digital game-based learning in high school computer science education: Impact on educational effectiveness and student motivation. Computers \& Education, 52(1), 1-12.

Pierce, R. U., \& Stacey, K. C. (2002). Algebraic insight: the algebra needed to use computer algebra systems. The Mathematics Teacher, 95(8), 622.

Pinto, M., \& Tall, D. (2002). Building formal mathematics on visual imagery: A case study and a theory. For The Learning of Mathematics, 22(1), 2-10.

Preiner, J. (2008). Introducing dynamics mathematics software to mathematics teacher: The case of GeoGebra. Dissertation in Mathematics Education, University of Salzburg, Austria.

Przenioslo, M. (2004). Images of the limit of function formed in the course of mathematical studies at the university. Educational Studies in Mathematics, 55(1-3), 103-132.

Roh, K. H. (2005). College students' intuitive understanding of the concept of limit and their level of reverse thinking. Doctoral dissertation, The Ohio State University.

Roh, K. H. (2008). Students' images and their understanding of definitions of the limit of a sequence. Educational Studies in Mathematics, 69(3), 217-233.

Roh, K. H. (2010). An empirical study of students' understanding of a logical structure in the definition of limit via the $\varepsilon$-strip activity. Educational Studies in Mathematics, 73(3), 263-279.

Ryan, R. M., \& Deci, E. L. (2000). Intrinsic and extrinsic motivations: Classic definitions and new directions. Contemporary Educational Psychology, 25(1), 54-67.

Reis, Z. A., \& Ozdemir, S. (2010). Using GeoGebra as an information technology tool: parabola teaching. Procedia-Social and Behavioral Sciences, 9, 565-572.

Saha, R. A., Ayub, A. F. M., \& Tarmizi, R. A. (2010). The effects of GeoGebra on mathematics achievement: enlightening coordinate geometry learning. Procedia-Social and Behavioral Sciences, 8 , 686-693.

Shadaan, P., \& Leong, K. E. (2013). Effectiveness of Using GeoGebra on Students' Understanding in Learning Circles. Malaysian Online Journal of Educational Technology, 1(4), 1-11.

Sıcak, A., \& Başören, M. (2015). Ortaöğretim öğrencilerinin akademik motivasyonlarının çeşitli değişkenler açısından incelenmesi (Bartın örneği). Bartın Üniversitesi Ĕ̆itim Fakültesi Dergisi, 4(2), 548-560.

Sierpińska, A. (1987). Humanities students and epistemological obstacles related to limits. Educational Studies in Mathematics, 18, 371-397.

Şataf, H. A. (2009). Bilgisayar destekli matematik öğretiminin ilköğretim 8. sinıf ögrencilerinin dönüşüm geometrisi ve üçgenler alt öğrenme alanındaki başarısı ve tutuma etkisi. Yayınlanmamış Yüksek 
Lisans Tezi, Sakarya Üniversitesi, Sosyal Bilimler Enstitüsü, Sakarya.

Tall, D., \& Schwarzenberger, R. L. E. (1978). Conflicts in the learning of real numbers and limits. Mathematics Teaching, 82,44-49.

Tall, D., \& Vinner, S. (1981). Concept image and concept definition in mathematics with particular reference to limits and continuity. Educational Studies in Mathematics, 12(2), 151-169.

Tall, D. (1992). The transition to advanced mathematical thinking: functions, limits, infinity, and proof. In D. A. Grouws (Ed.), Handbook of Research on Mathematics Teaching And Learning (pp. 495-511). Macmillan.

Taş, M. (2010). Dinamik matematik yazılımı GeoGebra ile ĕgrisel integrallerin görselleştirilmesi. Yüksek Lisans Tezi, İstanbul Üniversitesi Fen Bilimleri Enstitüsü, İstanbul.

Tatar, E., Kağızmanlı, T., and Akkaya, A. (2014). The effect of a dynamic software on the success of analytical analysis of the circle and prospective mathematics teachers opinions. Necatibey Faculty of Education Electronic Journal of Science and Mathematics Education Vol. 8, Issue 1, June 2014, pp. 153-177.

Ünlütürk Akçakın, H. (2016). GeoGebra destekli matematik öğretiminin ilköğretim öğrencilerinin akademik başarılarına ve motivasyonlarına etkisi. Yüksek lisans tezi, Gazi Üniversitesi Eğitim Bilimleri Enstitüsü, Ankara.

Vallerand, R. J., Pelletier, L. G., Blais, M. R, Brière, N. M., Sené $\neg$ cal, C., \& Vallières, E. F. (1992). The academic motivation scale: a measure of intrinsic, extrinsic, and amotivation in education. Educational and Psychological Measurement, 52, 1003-1017.

Wah, L. K. (2015). The effects of instruction using the arcs model and geogebra on Upper secondary students' motivation and achievement in learning combined transformation. Asia Pacific Journal of Educators and Education, 30, 141-158.

Williams, S. R. (1991). Models of limit held by college calculus students. Journal for Research in Mathematics Education, 22(3), 219-236.

Williams, K. C., \& Williams, C. C. (2011).Five key ingredients for improving student motivation. Research in Higher Education Journal. 10.03 .2020 tarihinde http://www.aabri.comwww.aabri.com/manuscripts/11834.pdf. adresinden erişildi.

Yıldız, F. (2008). "Oran, orantı ve yüzdeler” ünitesinin proje tabanlı ögrrenme ile ögrrenilmesinin matematik dersindeki başarlya ve tutuma etkisi. Yayınlanmamış yüksek lisans tezi, Marmara Üniversitesi, İstanbul.

Zengin, Y. (2011). Dinamik matematik yazılımı geogebra'nın öğrencilerin başarılarına ve tutumlarına etkisi. Yayımlanmamış yüksek lisans tezi, Kahramanmaraş Sütçü İmam Üniversitesi Fen Bilimleri Enstitüsü, Kahramanmaraş.

Zengin, Y., Furkan, H., \& Kutluca, T. (2012). The effect of dynamic mathematics software GeoGebra on student achievement in teaching of trigonometry. Procedia-Social and Behavioral Sciences, 31, 183187.

Zengin, Y. (2017). The potential of geogebra software for providing mathematical communication in the light of pre-service teachers' views, Necatibey Faculty of Education Electronic Science and Mathematics Education Journal. 11(1), 101-127.

\section{EXTENDED ABSTRACT}

Introduction: In the analysis course, it is revealed that students can easily perform operational algorithms, but they lack basic definition and interpretation information, and they have difficulties in conceptual understanding and association between concepts (Chappell \& Kilpatrick, 2003). One of the most basic concepts, that students have difficulties and various misconceptions (Özmantar \& Yeşildere, 2008) is limit that is related to the concepts of continuity, derivative, integral, series. Additionally, this concept is effective in developing mathematical thinking (Tall, 1992) and requires advanced mathematical thinking (Cornu, 1991). It is thought that preservice teachers' misconceptions about the concept of limit may negatively affect their learning about concepts such as continuity (Bezuidenhout, 2001), serial (Sierpinska, 1987) and their academic performance in other courses they took during their undergraduate education. Additionally, studies show that the majority of preservice teachers have difficulty 
interpretation of the $\varepsilon-\mathrm{N}\left(\varepsilon-\mathrm{n}_{-} \varepsilon\right)$ variables in the definition of convergence (Roh, 2008). Visualizations used in the teaching process is effective to interpretation of this formal definition and developing the concept image (Parks, 1996; Navarro \& Carreras, 2006; Kidron \& Zehavi, 2002; Öner, 2013). In addition, it comes to mind that methods and techniques, applied outside of traditional instruction can affect academic motivation which is one of the affective characteristics that has a significant effect on academic performance (Elliot \& Thrash, 2001; Matuga, 2009). The software GeoGebra is one of the techniques regarding visualization (Kağızmanlı \& Tatar, 2012) which has an important role in the learning and teaching of the concepts in the analysis course (Pinto \& Tall, 2002) and can provide richer applications, in order to compared to traditional instruction. Therefore, it is important to investigate the effect of GeoGebra-supported instruction to cognitive and affective skills

Materials and Methods: In this study, pre test-post test control group experimental design was applied to investigate the effect of GeoGebra, on preservice elementary mathematics teachers' academic performance and motivation. In this study to determine academic performance of preservice elementary mathematics teachers, Performance Test of Analysis, prepared by researcher was used. At the same time, Academic Motivation Scale, prepared by Vallerand et al. (1992) and adapted by Karagüven (2012) was used to determine academic motivation. In the application process, visual materials developed by GeoGebra, connected with concepts of arithmetic sequence, geometric sequence convergence, divergence, monotone sequence, infimum, supremum, were exploited. Materials were developed by the researcher using GeoGebra software with the idea that preservice teachers can contribute to the learning process. Performance Test of Analysis and Academic Motivation Scale were applied as pre-test and post-test before and after the application process. In order to analyze obtained data, descriptive istatistics, dependent samples t-test, independent samples t-test, Wilcoxon Signed Rank test, Mann Whitney U test were used.

Findings: As a result of study, the mean post test scores of experimental group related geometric and general performances showed statistically significant difference from mean post test scores of control group (U=208; $U=$ $241 ; \mathrm{p}<.05)$ however, there is no significant difference between the experimental and control groups with respect to algebraic performance $(\mathrm{U}=381 ; \mathrm{p}>.05)$. In this case, it can be said that analysis courses conducted with GeoGebra assisted instruction positively affect the geometric performance and consequently overall performance of preservice teachers. As a result of independent samples t-test, there was no significant difference between experimental and control groups' academic motivations towards Academic Motivation Scale post test scores $(\mathrm{t}=1.23 ; \mathrm{p}>.05)$. This indicates that analysis courses conducted with GeoGebra-supported instruction and traditional instruction do not create difference in the academic motivations of preservice teachers.

Discussion: The result of study, significant differecence were found between groups' academic performances in favor of experimental group. In the literature, there are studies,regarding traditional instruction is not enough and GeoGebra-assisted instruction is positive impact on the learning process (Dikovic, 2009; Shadaan \& Leong, 2013) increases the level of academic performance (Saha, Ayub \& Tarmizi, 2010; Gómez-Chacón \& Escribano, 2011; Zengin, Furkan \& Kutluca, 2012; Güven \& Yılmaz, 2012; Tatar, Kağızmanlı \& Akkaya, 2014; Kan, 2014; Aydos,2015; Acar, 2015; Bhagat \& Chang, 2015; Ünlütürk-Akçakın, 2016; Kepçeoğlu \& Yavuz, 2017; Ocal, 2017; Çekmez \& Baki, 2018) and makes learning easier (Taş, 2010; Reis \& Özdemir, 2010). In this study, significant differecence were found between groups' geometric and ovarall performances in favor of experimental group however there is no significant difference between the experimental and control groups with respect to algebraic performance. In this case, it can be said that the significant difference on academic performance of preservice elementary mathematics teachers in experimental group stemmed from increasing their geometric performance. GeoGebra- assisted instruction, due to the efficient use of time it allows more opportunities to deal with the desired goals (Aktümen, Y1ldı, Horzum \& Ceylan, 2011) and provides the opportunity to associate the representations of concepts (Kan, 2014). Therefore preservice teachers may have interprated graphics with algebraic expressions of the concepts. In addition, although there is no significant difference between the experimental and control groups with respect to algebraic performance it was determined that traditional instruction and GeoGebra-supported instruction process similarly positive affected algebraic performance. It is thought that this may be due to the fact that the preservice teachers were more familiar with the questions expressed with algebraic representation than the graphical representation.

Otherwise, there is no significant difference between the experimental and control groups with respect to academic motivation. Although a person's affective learning is the product of the interaction between their 
abilities and their environment, affective characteristics such as faith, attitude are stereotypes, difficult to change, and in some cases can overcome the positive effects of the lecturer or the teaching process (Tekin, 2003). However, affective field learning occurs longer than cognitive learning and sometimes occurs after the completion of the teaching process. Since this study takes place over a period of time that cannot be characterized as long, it is difficult to determine, although there may be a change in affective dimension (Balaban-Sal1, 2006). As a result of this study, despite of the academic performance of preservice teachers in the experimental groups' differentiation in the positive direction and there is a strong relationship between academic performance and motivation (Neisi \& Yamini, 2010), it is remarkable result that the levels of academic motivation, that means in the state of willingness to act in an academic sense to reveal behavior, did not change. Although this situation is an issue that needs to be investigated, it is thought that this result may be caused by other variables that affect motivation in the teaching process such as gender, class level, active participation, attitude (Williams \& Williams, 2011) and lecturer.

Conclusion and Suggestions: In the light of the findings, suggestions have been made as:

- Different methods and techniques from traditional teaching should be used too to eliminate students' misconceptions about the concept of limit to enrich their concept image and to make them understand the formal definition.

- In order to ensure the preservice teachers' develop images that are compatible with the definition and complete their incomplete images, GeoGebra software, found to have positive reflections on the teaching process in this study, can be used.

- More studies can be conducted to determine the variables that affect motivation, which is one of the important affective characteristics that are effective in the teaching process 